Hispania Sacra, LXII

126, julio-diciembre 2010, 723-756, ISSN: 0018-215-X

\title{
CATÓLICOS Y NACIONALISTAS VASCOS: LAS ELECCIONES DE FEBRERO DE 1936 Y LA GUERRA*
}

\author{
POR \\ CRistóbal Robles MuÑOZ \\ CCHS, CSIC, Madrid.
}

\section{RESUMEN}

Fue evidente la división de los católicos vascos, entre los nacionalistas y quienes creían que las elecciones legislativas de febrero de 1936 eran la hora de la verdad, frente a la amenaza revolucionaria de la izquierda. Se estudia las consecuencias políticas de la decisión del PNV de ir solo a los comicios y las tensiones de aquellos meses. Las expectativas de concordia, despertadas por el primer mensaje de Azaña, se hundieron ante algunas medidas del Gobierno y una cadena de hechos consumados, que parecían abrir paso a la revolución, sobrepasando y violando la Constitución.

Se incorpora a este trabajo los datos conocidos tras la apertura de los archivos de la Santa Sede para el período de Pío XI.

PALABRAS ClAVE: Nacionalistas Vascos, Santa Sede, II República, Elecciones de 1936. Gobierno Vasco, Guerra civil.

* Este trabajo se ha hecho en el marco del proyecto de investigación HAR2008-01002: «España y la Santa Sede en la Europa de entreguerras. Una perspectiva comparada (1930-1939)», Ministerio de Ciencia e Innovación. Secretaría de Estado de Universidades.

Siglas:

ASV AES Spagna IV: Affari Ecclesiastici Straordinari Spagna, IV periodo, posizione e fascicolo, folio.

ASV Arch.Nunz.Madrid: Archivo Segreto vaticano, Acrhivio Nunziatura di Madrid, caja y folios

Tc: telegramma cifrato 


\title{
CATHOLICS AND BASQUE NATIONALISTS: THE FEBRUARY ELECTIONS 1936 AND THE WAR
}

\begin{abstract}
It was clear the division of the Catholic Basques, with nationalists and those who believed that the parliamentary elections of February 1936 were the moment of truth face the threat of the revolutionary left. It studies the political consequences of the decision of the PNV to go alone to the polls and tension of those months. The expectations of harmony, sparked by the first message Azaña, sank to some measures of the Government and a string of facts that seemed to make way for the revolution, exceeding and violating the Constitution.
\end{abstract}

KEY WORDS: Basque Nationalists, the Vatican, Second Republic, Elections 1936. Basque Government, Civil War.

Recibido/Received 20-11-2009

Aceptado/Accepted 04-03-2010

Convocadas las elecciones legislativas para el 16 de febrero de 1936, José Horn y Areilza comunicó el 14 de enero de 1936 al nuncio, Federico Tedeschini, su intención de viajar a Roma. El nuncio informó inmediatamente. «Basta che io dica che si tratta di nazionalisti vaschi perchè vostra Emza. sia sufficientemente prevenuta». Iban en la comitiva los diputados y los miembros vascos del Tribunal de Garantías. El objetivo del viaje, decía Horn Areilza en su telegrama del 19, era tratar de «altos intereses religiosos no reducidos a temas políticos impropios de una gestión tan importante». ${ }^{1}$

La prevención del nuncio revela lo que en esos momentos se denunciaba. El objetivo real de los cinco diputados y de los miembros del Tribunal de Garantías era «enmudecer inmediatamente al Sr. Urquijo en la briosa campaña que realiza La Gaceta del Norte para constituir en todo el País Vasco un frente contrarrevolucionario que luche declaradamente contra la revolución y contra sus cómplices, que, en el País Vasco, son hoy los nacionalistas». ${ }^{2}$ Regresó la comisión sin ser recibida por el Papa ni por Pacelli. Estuvo con Giuseppe Pizzardo.

17815 Tedeschini-Pacelli, 16 enero 1936, ASV Arch.Nunz.Madrid 913 648. Carta y telegrama de Horn Areilza, 14 y 19 de enero, ib 642-643 y 647. Las elecciones a vocales del Tribunal fueron el primer signo de cambio político desde junio de 1931. Tras ese acto, celebrado el 3 de septiembre, Alcalá Zamora negó su confianza a Azaña, que dimitió el día 12. Le sucedió Alejandro Lerroux. Sobre esta institución, Martin Bassols Coma, La Jurisprudencia del Tribunal de Garantías Constitucionales de la II República. Española, Madrid, Centro de Estudios Constitucionales 1981, 11-86. Vid. la introducción de Jorge Urosa, Enrique San Miguel, Ignacio Ruiz y Francisco Marhuenda a El Libro de Actas del Tribunal de Garantías Constitucionales, Madrid, Comunidad de Madrid, Biblioteca Académica 1999, 9-45.

${ }^{2}$ Así se consignaba en un texto que José María de Urquijo envió al nuncio el 20 de enero para ver si debía publicar ese telegrama recibido de Roma. Posiblemente el texto lo entregó Francisco de Luis, director de El Debate, ibidem 646.

Hispania Sacra, LXII

126, julio-diciembre 2010, 723-756, ISSN: 0018-215-X 


\section{«CRUZADA CONTRARREVOLUCIONARIA ${ }^{3}$}

«Cruzada contrarrevolucionaria», con este titular a seis columnas y en rojo, comenzó La Gaceta del Norte su campaña electoral. ${ }^{4}$ Había que vivir aquellas jornadas, puestos «en tensión todos los músculos del espíritu» para juntar y unir los hombres que pararan a la revolución. Todas las candidaturas que se formaran contra ella y sus cómplices tendrían su apoyo, sin mirar su ascendencia política, incluidos los nacionalistas, y desde los tradicionalistas hasta los republicanos independientes. Ahora, a ganar en las urnas. Luego, a obtener esa victoria que sólo se alcanza con la justicia y el amor. ${ }^{5}$

No al regreso de Azaña, portavoz y guía del Frente Popular y de su política ${ }^{6}$ y liquidación del «octubre rojo» eran los dos objetivos. ${ }^{7}$ En las asambleas carlistas, celebradas a finales de 1935, se empleó un lenguaje cada vez más violento, sobre todo en Cataluña. Todos los dirigentes del partido hablaban de preparación militar y de la proximidad de la batalla. Había que morir antes que ceder y antes de morir, había que luchar, dijo Manuel Fal Conde. ${ }^{8}$

${ }^{3}$ En una posdata a, Unamuno resumía el ambiente esas jornadas y su manifestaba su opción: «¿Revolución? ¿Contra-Revolución?» ¡Entendimiento!», en «La hipnosis de la herencia», Ahora 5 febrero 1936, en Ensueño de una patria. Periodismo republicano 1931-1936, edición de Víctor Ouimette, Valencia, Pre-textos 1984, 267.

4 Justificaría su decisión, en que era un deber de conciencia. «Los «perros mudos», La Gaceta del Norte, 19 de enero 1936, 8.

5 «Preludio de una campaña electoral. Invitación y ofrecimiento», La Gaceta del Norte, 10 de enero 1936,1 .

${ }^{6}$ Hay un retrato de Azaña, que revela algunos rasgos indiscutibles de su personalidad, al menos hasta que conoció la derrota tras los sucesos de octubre de 1934. Hombre altivo y soberbio, antes que nada era un intelectual que dudaba por sistema y desdeñaba a cuantos tenía a su alrededor. De ahí que fuera implacable y extraordinariamente mordaz en la crítica, incluso cuando los saetazos alcanzaban a sus más íntimos colaboradores». No era persona de transacciones. «Diestro conversador y uno de los mejores prosistas de su tiempo, la política le repugnaba en lo que tiene de intercambio y comunicación directa de sentimientos e ideas. Reservado e introvertido, se movía a disgusto en ese terreno, en el que muy pronto manifestaba un radical sectarismo». Quizás la clave para entender ese rasgo sea su incapacidad para discutir en un plano de igualdad. Su oratoria, «a veces fascinante y demoledora», fue siempre «fría y monótona». José Maria Gil RoBles, No fue posible la paz, Barcelona Planeta 1968, 457. Tras la dimisión en septiembre y la derrota electoral de Azaña en noviembre de 1933, Unamuno dijo de Manuel Azaña que era y actuaba como «sumo definidor y sumo pedante de la supuesta revolución». «Del año 1933 al 1934», El Sol 14 enero 1934, en Ensueño de una patria... 163-167.

7 «La voz del pueblo. Su coincidencia reconfortante con todos sus jefes», La Gaceta del Norte, 11 de enero, 1. Una caricatura presentaba a los tres jefes de la izquierda republicana con unas muletas que expresaban el ayuda sindical que les prestaban la UGT, la CNT y la FAI. «Los inválidos... o ya se ve el pie de qué cojean», La Gaceta del Norte, 12 de enero, 1.

${ }^{8}$ En una reunión celebrada en San Sebastián, habló de «gritos de guerra y de lucha». Martin BlinkHorn, Carlismo y contrarrevolución en España. 1931-1939, Barcelona, Crítica 1979, 307. Una síntesis, Eduardo GonZÁlez CALLEJA, «Aproximación a las subculturas violentas de las derechas antirrepublicanas españolas (1931-1936)», Pasado y memoria. Revista de Historia Contemporánea 2 (2002) 5-90, edición digital. 
No aceptarían la invitación ni el ofrecimiento los nacionalistas, pues en nada se distinguían ya de Acción Nacionalista Vasca. Habían olvidado la primera parte de su lema. Se acercó ANV a Azaña. Un sector, encabezado por Andrés Perea, dejó el separatismo para definirse como autonomista. Esta posición la asumió en enero de 1936 Acción Vasca, el semanario dirigido por Perea y portavoz de la dirección de ANV. Había que volver a unirse con las izquierdas. Como programa, llevó ante sus electores la aprobación del Estatuto. Se aliaría con el Frente Popular, porque este era «autonomista». Tenía formulado ya un programa, cuyas metas definían a ANV como nacionalista y socialista. ${ }^{9}$

No rectificaron los dirigentes del PNV la ruta iniciada el 12 de junio de 1934. Continuaban a remolque de la izquierda. A pesar de eso, la mano tendida, decía La Gaceta del Norte. A pesar del rechazo de los nacionalistas, a nadie habría que excluir en el llamamiento, porque, también en esta ocasión, había que «hartarse de razón y de autoridad», tener una «táctica tolerante y comprensiva» y «espíritu generoso».

El 12 de enero, en el frontón Euskalduna, de Bilbao, el PNV dijo que ellos no iban ni con los revolucionarios ni con los que se confesaban enemigos de la revolución. Estaban por encima de esa confrontación y pedían la amnistía para los que habían ido engañados a la revolución. Se avergonzaban de marchar con la derecha.

Prescindiendo de la controversia ideológica, había que echar números. En las elecciones del 19 de noviembre de 1933, los nacionalistas ganaron porque La Gaceta del Norte, puesta $a$ su favor, les proporcionó un excedente, que les permitió superar en más de seis mil votos a la izquierda. Esta fue entonces dividida, al presentar los radicales socialistas en Bilbao candidatura propia. Si la derecha se presentara unida el 16 de febrero, aventajaría a la izquierda por encima de catorce mil votos. ${ }^{10}$

Ganarían los nacionalistas derrotando la mentira, la impostura y todas las artimañas de los aliados de la revolución, la derecha anti-vasca. ${ }^{11}$ Esa agresión

\footnotetext{
${ }^{9}$ En este acercamiento a la izquierda a través de Azaña coincidieron ANV y PNV, que votaron con la izquierda su candidatura a la presidencia de la República. El PNV otorgó en abril su confianza al gobierno presidido por Azaña. José Luis de la GRANJA SÁINZ, Nacionalismo y II República en el País Vasco: estatutos de autonomías, partidos y elecciones: historia de Acción Nacionalista Vasca, 1930-1936, Madrid, Siglo XXI 2008, 508, 513-528, 579 y 598.

10 «Contra la revolución y sus cómplices en Bilbao (como en todas partes)» y «Verdades axiomáticas» La Gaceta del Norte, 17 y 23 de enero, 1. En un recuadro se destacaba que la división del voto daría el triunfo a los enemigos de la Iglesia. Con ello, los nacionalistas continuaban la senda elegida cuando viraron a la izquierda «el aciago 12 de junio de 1934».

$11 \ll_{i}$ Por la libertad patria! Y por la verdad cristiana contra las falsedades de "La Gaceta”, $i L a$ candidatura triangular!, Contra la candidatura triangular de "La Gaceta", Contra la labor obstaculizadora de "La Gaceta", La defección "triangular" de "La Gaceta" y sus mentiras para regalar dos actas a los 
permanente, casi obsesiva, ocultaba la existencia de un «puente hacia una secreta inteligencia con las izquierdas... para combatir la fuerza indomable y poderosa del nacionalismo vasco». Era necesario arrojar fuera las caretas. El tono de la polémica no descendió. ${ }^{12}$ Se había convertido La Gaceta del Norte en «el órgano del antinacionalismo de todos los sectores y matices». ${ }^{13}$ La polémica tuvo un aire macabro. ${ }^{14}$

La respuesta de los nacionalistas fue fulminante. La Gaceta del Norte temía represalias. Odiaba más al nacionalismo que a la revolución. José María de Urquijo era el jefe y el fautor de la unión de las derechas, en las que formaban José María Gil Robles y Alejandro Lerroux, enemigos del Estatuto, del concierto económico, de la lengua vasca y promotores de una ley de reforma agraria que permitió los desahucios de campesinos. ${ }^{15}$

«Lucharemos. Y nuestros esfuerzos lograrán derrotar a los sectarios, lograrán que el comunismo no gane un puesto en Bilbao, ni aun con la ayuda terminante, el apoyo indudablemente eficaz que le prestan la defección, el abandono, la huida de don José María de Urkixo, cuya conducta al desnudo exponemos al juicio de los católicos bilbaínos». ${ }^{6}$

El 1 de febrero las candidaturas contrarrevolucionarias de las cuatro provincias del País Vasco lanzaron un manifiesto conjunto. Evocaban los sucesos de Eibar y Mondragón en 1934. El buen sentido de los verdaderos vascos, con sus votos, conseguiría acabar con todo lo que había menguado la dignidad de país y

rojos, Una impostura más de "La Gaceta" que va desde la mentira a la delación, La delación. arma muy cristiana de "La Gaceta" y, sobre todo, muy respetuosa con el poder espiritual», Euzkadi, 16-19, 21-23 de enero, 1. «Se invoca la antirrevolución para combatir exclusivamente al nacionalismo, única fuerza auténticamente contrarrevolucionaria», Euzkadi, 31 de enero, 1.

12 «Votar "La Gaceta" es votar el comunismo e ir contra los hombres que han defendido en el Parlamento de Madrid, la civilización cristiana», Euzkadi, 25 de enero, 1. En ese número, «Se cogió los dedos», p. 3. Es una caricatura de José María de Urquijo con un remiendo en su pantalón, en el que figura marcada la flor de lis.

13 «Don José María escribe... mintió y miente con cínico descaro», Euzkadi, 6 de febrero, 3.

${ }^{14} \mathrm{~K}$. firmaba una caricatura. Un nacionalista, con pala en la mano. Y este texto: «Los candidatos: -Hermano cocinero, morir, habemus. Don José María: -Ya lo sabemos. El nacionalista: -Y nosotros os enterraremos». «Candidus, candidatus», Euzkadi, 28 de enero, 1. Sobre la complicidad de los nacionalistas en el asesinato de Urquijo, José María de Urquijo. Opinión, religión y poder, Madrid, CSIC 1997, pp. 678-671.

15 K., «Una coronación», Euzkadi, 1 de febrero, 3.

16 «Contra los cómplices de la revolución. En este caso, quienes abandonan cobardemente el campo al enemigo», Euzkadi, 29 de enero, 1. «Las izquierdas representan en esta ocasión el sectarismo. Las derechas, la deserción, la cobardía, el abandono del campo al enemigo, la entrega al comunismo de dos actas ¡por Bilbao!». «Derechas e izquierdas, Los que no desertan, Ni la conjuración de odios, ni de la defección, lograrán que Bilbao tenga un representante comunista. Porque el Partido Nacionalista no deserta ante el enemigo, Euzkadi, 2, 4, 8 de febrero, 1. 
amenazaba el orden social. ${ }^{17}$ Para estimular el voto útil y desviar hacia la derecha el nacionalista, La Gaceta del Norte, durante varios días y a partir de la segunda semana de febrero, recuadró un texto del cardenal Gomá, bajo este titular, «Dios, antes que la patria»..$^{18}$

En vísperas electorales, había que resumir el itinerario seguido y fijar la posición: no se podía vencer a la izquierda sin la unidad. Era un caso evidente de aplicación del mal menor. Y había una trayectoria política que permitía decidir con acierto. Se apartó de ella el PNV. ${ }^{19}$

Los nacionalistas negaban la condición de católico a los que no militaban en sus filas. ¿Era verdad? ¿Era justo? Respondían los hechos. Participaron en la rebelión de los ayuntamientos. Acudieron con Indalecio Prieto a Zumárraga. Los sindicalistas de la Solidaridad de los Trabajadores Vascos participaron en octubre de 1934 en la huelga revolucionaria. Y Euzkadi injurió esos días a la Guardia Civil. «Artibai», fue citado ante la autoridad judicial por la traducción «amañada» de un artículo suyo publicada en $L a G a$ ceta del Norte.

Los nacionalistas recordaron que José María de Urquijo fue llevado ante los tribunales por un delito de subversión y que su periódico fue denunciado por difamación, al publicar una fotografía trucada en la que se presentaba a la fuerza pública cargando contra un grupo de pacíficos estudiantes. ${ }^{20}$

El clima fue cada día mas tenso. Urquijo estaba ayudando a anarquistas y comunistas. No bastaba declararse anti-revolucionario. Había que actuar como tal.

\footnotetext{
17 «Magnífico manifiesto que significa Unión, Unión y siempre Unión», La Gaceta del Norte, 2 de febrero, 1. La versión al euskera, ib. 16.

${ }^{18}$ Esa afirmación del cardenal primado acusaba a la derecha, cuyas afirmaciones «españolistas» ponían por delante de la religión su «nacionalismo». Sabino Arana colocó siempre por encima de todo a Dios. Sólo por Él había resonado su grito de libertad en favor de los vascos. «Dice el cardenal Gomá», Euzkadi, 31 de enero, 1.

${ }^{19}$ Esta afirmación de La Gaceta del Norte, fue tachada de «irrespetuosa y mentirosa». Fue Urquijo quien no respetó las normas pontificias en materia electoral. Su conducta era una ficción. Bajo apariencia de sumisión y obediencia, se dejaba arrastrar por «la soberbia y la rebeldía». «Bizkaya elegirá siete diputados cristianos, nacionalistas, para representarla en las Cortes de Madrid» y «Las normas interpretadas por don José María de Urkixo», Euzkadi, 14 y 15 de febrero, 1.

${ }^{20}$ La fotografía, cuyo montaje fue ordenado por el «nefasto» Urquijo, la volvió a publicar Euzkadi el 12 de febrero, en su página tercera. «¡Don José María de Urkixo, “defensor» de la fuerza pública” y "Odio, falsedad y ruindad. Las armas con que se nos combate"», Euzkadi, 8 de febrero, 1 . En este mismo número, una caricatura presentaba la gratitud de la CNT a La Gaceta del Norte, por haber aplastado a los nacionalistas con sus mentiras, ibidem 3. El 11 de febrero el mismo motivo en el titular a seis columnas. «Si te combaten el odio, la falsedad y la calumnia, ¿cómo será posible, pueblo nacionalista, que no venzas?».
}

Hispania Sacra, LXII

126, julio-diciembre 2010, 723-756, ISSN: 0018-215-X 
No podía perderse ni un voto. ${ }^{21}$ En los comicios que estaban en juego la seguridad y la libertad. ${ }^{22}$ Los nacionalistas celebraron un gran mitin el viernes 14 de febrero. ${ }^{23}$ Los nacionalistas combatían la llamada «candidatura triangular» pues representaba el poder del dinero y la nostalgia de la monarquía. Los vascos, rotas su cadenas, pasarían por encima de esos intereses, luchando por sus legítimos derechos. ${ }^{24}$

\section{Mateo Múgica y Las ELECCiOnes}

El PNV se presentó solo. No se integró ni en la coalición de derechas ni en el «bloque revolucionario». El 14 de febrero de 1936, escribió Mateo Múgica una dramática carta al nuncio. Había una campaña contra los nacionalistas, que se negaron a unirse a la derecha, después de la maniobra de ésta contra el Estatuto y de los sucesos de octubre de 1934.25

El obispo de Vitoria afirma que los que se hacían pasar por portavoces de la Iglesia ignoraban la realidad electoral de Vizcaya. Negar su apoyo a los nacionalistas sería permitir el triunfo de la izquierda. La situación era tan grave que envió a Madrid al canónigo Antonio Pildain para que informara con detalle al cardenal Tedeschini.

Las peores previsiones se cumplieron. La derecha perdió por casi 40000 votos en Bilbao. Eso permitió que la izquierda sacara 4 diputados y los nacionalistas, 2. En la provincia de Vizcaya, los nacionalistas fueron al copo y se hicieron con los 3 escaños. En Guipúzcoa, salieron 4 nacionalistas y 2 de izquierdas. Hubieran copado, si las derechas no se hubieran retirado en la segunda vuelta. ${ }^{26}$

En su balance, Mateo Múgica apuntaba que, en Vizcaya, ningún partido católico estaba libre de responsabilidades. Fal Conde dijo en Bilbao que, con los nacionalista, ningún acuerdo, aunque suscribieran íntegramente el programa de

21 «Hay que disputar el triunfo voto a voto, como si de cada uno dependiera el honor de España». «Se calcula en 800000 el número de oyentes que ayer tuvo la arenga del jefe de la Ceda a los españoles», La Gaceta del Norte, 16 de febrero, 3.

22 «A ti, elector bilbaíno. Unas palabras serenas» y «Punto final sobre la cuestión electoral», $L a$ Gaceta del Norte, 13 y 14 de febrero, 9 y 1 y 10. « Nacionalistas, vascos todos! La religión de tus padres, los destinos de tu pueblo, la paz social entre tus hermanos, te piden hoy un esfuerzo más. ¡No desoigas sus clamores y cumple con tu deber!», Euzkadi, 16 de febrero, 1.

23 «El gran mitin de anoche en Euskalduna», Euzkadi, 15 de febrero, 1 y 3-5. En su discurso, José María de Izaurieta, candidato por Bilbao, subrayó el antagonismo de Cristo y de la tradición vasca con el marxismo.

${ }^{24}$ Cartel reproducido en primera página sin título, Euzkadi, 16 de febrero.

25 José Luis de la Granja SAInZ, Nacionalismo y II República... 566-595.

${ }^{26}$ Esa retirada, dice Mateo Múgica, fue una represalia porque había dicho, a instancias de los dirigentes del partido, que los nacionalistas eran católicos. 
la derecha. El Pueblo Vasco, diario monárquico alfonsino, publicó que era una vileza tener cualquier relación con los nacionalistas. Juan Pablo Lojendio, de la CEDA, se trasladó a Bilbao, para buscar la unidad, pero fracasó. Antonio Pildain fue a Bilbao, pero no lo recibió Urquijo. Los nacionalistas respondieron con igual encono.

En Álava se hicieron la guerra los tres candidatos, José Luis Oriol, tradicionalista, Estrada, de la CEDA, y Landáburu, nacionalista. Naufragaron los esfuerzos de Antonio Pildain para conseguir una sola candidatura.

En Guipúzcoa los nacionalistas se resistieron a la unidad, porque la reclamaban para las tres provincias. Temían que la victoria de la derecha fuera la aniquilación del PNV. Los oradores de la derecha decían que los nacionalistas no se merecían ni el saludo y que habría que colocarlos fuera de la ley. Atacaban los otros católicos a las personas que juzgaban no beligerantes con los nacionalistas. La Constancia, integrista, y El Diario Vasco, de Renovación Española, eran implacables con ellos.

Los nacionalistas creían que ganarían yendo solos, seguros de que los seguirían masivamente los católicos y la derecha. No necesitaban pactar. Las derechas los habían acusado de anticatólicos. Atacaban al obispo, porque dijo que, en esa consideración de católicos, para nada entraban motivos políticos.

¿Podía negar ese hecho un obispo? Los nacionalistas y sus organizaciones eran confesionalmente católicos ¿Por qué no aceptaron los otros la gran fuerza de los nacionalistas? Sólo la Solidaridad de los Trabajadores Vascos, Euskal Langileen Alkartasuna, tenía 40000 afiliados. ${ }^{27}$

Según prometió en su entrevista en Madrid, Antonio Pildain envió a Tedeschini su análisis de los resultados electorales.

$\begin{array}{ll}\text { La izquierda } & \text { 256 escaños y } 4358559 \text { votos } \\ \text { La derecha } & 143 \text { escaños y } 4570744 \text { votos } \\ \text { Centro } & 55 \text { escaños y } 340073 \text { votos } \\ \text { Nacionalistas vascos } & \text { 12 escaños y } 141137 \text { votos }\end{array}$

Las previsiones de La Gaceta del Norte fallaron. La estrategia montada sobre su error dio la victoria a la izquierda, por los motivos que explicó en su carta del 3 de marzo Mateo Múgica. Faltó mesura y alteza de miras y sobró pasión. ${ }^{28}$

\footnotetext{
${ }^{27}$ Cartas de Mateo Múgica-Tedeschini, 14 de febrero y 3 de marzo 1936, ASV Arch.Nunz.Madrid 913 652-659.

${ }^{28}$ Había dicho el diario de Urquijo que había un gran entusiasmo y que iban a ganar. De doce candidatos patrocinado por él, sólo salió elegido uno. De los 12 nacionalistas, salieron elegidos 9. PildainTedeschini, 4 marzo, ASV Arch.Nunz.Madrid 913 661-662.

Hispania Sacra, LXII

126, julio-diciembre 2010, 723-756, ISSN: 0018-215-X
} 
En el Vaticano consideraban grave la situación, pero creían que la suma de todos los que no formaban el Frente Popular podría ser una fuerza resistente, a tener en cuenta en las Cortes. ${ }^{29}$ Los datos no coincidieron con esta primera impresión del Cardenal Tedeschini.

La derecha anti-vasca se alineará en 1936 al lado de la rebelión militar y contra las libertades vascas. ${ }^{30}$

\section{TRAS LAS ELECCIONES, EXAMEN}

Apuntaban los nacionalistas vascos al problema agrario para rechazar una alianza con la CEDA. Había más. Los nacionalistas tenían organizaciones sociales sensibles también a las amenazas a los derechos conseguidos esos años. Basta recordar la fuerza del sindicato nacionalista. No era sólo el Estatuto la razón de su desconfianza hacia quienes habían gobernado desde 1934.

Es interesante ver el análisis que llegó a Federico Tedeschini sobre los resultados electorales en Cáceres. ¿Por qué habían perdido las derechas? No fue por abusos y coacciones, porque las fuerzas del orden estaban a su lado. Sus electores en 1933 habían cambiado su voto. Se les prometió «una política social protectora», que amparara sus legítimas aspiraciones. En cambio, muchos arrendatarios fueron arrojados de las tierras que, desde hacía muchos años, venían cultivando, mediante desahucios que los dejaron en la miseria. $^{31}$

Se elevaron abusivamente las rentas, duplicándola en muchos casos. En la aparcería se volvió al sistema de «medias». La calidad de la tierra convertía en leonina esa forma de contrato, dejando a los campesinos sin tierras y con jornales de hambre.

${ }^{29}$ Tc 37859 y 7875 Tedeschini-Pacelli, 18 febrero y 3 marzo y respuesta 939/36 Pacelli-Tedeschini, 17 marzo, ASV Arch.Nunz.Madrid $900521-529$ y 552-557 y 565.

30 Entre los elementos disconformes con la República, enumera Aguirre el 9 de marzo de 1937 «a las juventudes idealistas de ardiente fe religiosa que luchaban y que luchan ¡cómo no! por lo que ellos entienden por la verdad». pero a su lado, estaban también «el gran capitalismo, los grandes financieros, los grandes terratenientes, los que a toda costa quieren conservar un pasado causante de todaslas desgracias presentes. Creyentes, pocos en general; materialistas, muchos; de fe acomodaticia, cuantos (sic)». En el borrador el párrafo terminaba así: «masones, no pocos»

31 Tras los sucesos de octubre, el cardenal Vidal i Barraquer pidió el 20 de octubre a sus diocesanos, especialmente a los ricos, que cumplieran sus obligaciones de justicia y de caridad. Texto catalán y español, Arxiu Vidal i Barraquer. Església i Estat durant la Segona República Espanyola 1931-1936. Textos en la llengua original, Edició a cura de M. Batllori i V. M. Arbeloa, IV 10 d'octubre de 1933-18 juliol 1936, 1a i $2^{\text {a }}$ Part, Monestir de Montserrat 1986, 588-594. 
Todos esos factores se agravaron con el problema del trigo y con el aumento del paro. Habían seguido echando a aparceros, incluso después de convocadas las elecciones, valiéndose de la guardia civil.

Se pedía el voto a quienes habían sido víctimas de estos abusos sin que la derecha los hubiera protegido. Todos los colonos, los echados de sus tierras, votaron al Frente Popular. En algunos pueblos la derecha no pasó de un centenar de votos y la oposición superó el millar.

Erró Acción Popular al hacer candidaturas contra-revolucionarias. ${ }^{32}$ Fue una provocación a los campesinos. Representaban sólo a los capitalistas, la aristocracia y la gran burguesía. La pequeña burguesía, los pequeños propietarios, los arrendatarios, los aparceros, los braceros, no se sentían defendidos por ellas. Los votantes habían castigado ese afán de acaparar los escaños. «Estos hombres torpes y egoístas nos han lanzado a una aventura que sólo Dios sabe en lo que puede terminar». Gil Robles había sido engañado. ${ }^{33}$ Derrotada la derecha, los campesinos estaban preparando la ocupación de fincas. ${ }^{34}$

En «el País Vasco-Navarro» se cumplió lo previsto, aseguró La Gaceta del Norte. Los resultados en la mañana del martes 18 de febrero eran los siguientes: la derecha, 14, con 7 en Navarra, donde obtuvieron el copo, 2 en Vizcaya provincia, los 4 puestos por la mayoría en Guipúzcoa, y en Álava, 1 de los dos, quedando para la segunda vuelta la posibilidad de que Luis P. Flórez Estrada consiguiera vencer y obtener también un copo.

Los nacionalistas, 4 diputados. Irujo por la minoría en Guipúzcoa y pendiente de la segunda vuelta, Horn y Robles, por la minoría en Vizcaya-Bilbao, y Aguirre por Vizcaya-provincia. ${ }^{35}$

La única nota preocupante, según La Gaceta del Norte, era la encrucijada en que se hallaban los nacionalistas. El PNV estaba «viviendo las horas más críticas y difíciles de su existencia: y o da un freno en su alocada y vertiginosa marcha, según hace ya año y medio que lo advertimos y aconsejamos por su propio

\footnotetext{
32 Para la corriente más social, vid. Javier TuSELl y José CALvo, Giménez Fernández, precursor de la democracia espanñola, Madrid, Sevilla, Mondadori y Diputación Provincial de Sevilla, 1990.

${ }^{33}$ Sobre la CEDA y la diversidad de fuerzas que en ella se integraron, José R. MonTERo GibERT, $L a$ CEDA. Catolicismo social y político en la II República, Madrid, Ediciones de la Revista del Trabajo, 1977.

${ }^{34}$ Creía Tedeschini que este informe, del 26 de febrero, reflejaba lo sucedido en otras provincias. Lo envió como anexo a 7877 Tedeschini-Pacelli, 3 marzo 1936, ASV Arch.Nunz.Madrid 912 560-563 y 568

35 «Hemos triunfado en el País Vasco-Navarro», La Gaceta del Norte, 18 de febrero, 10-18. En la página 20, el reportaje gráfico venía enmarcado en una llamada a la serenidad, a la unión y a la disciplina. Esta información fue irónicamente rectificada. «Cómo informa "La Gaceta" a sus lectores», Euzkadi, 3 de marzo, 5. Se reproducía esta información, suprimiendo a siete de los catorce candidatos fotografiados como triunfadores y que no salieron elegidos el 1 de marzo.
}

Hispania Sacra, LXII

126, julio-diciembre 2010, 723-756, ISSN: 0018-215-X 
bien, o deriva definitivamente un gran sector del mismo hacia la izquierda, paralelamente a la Esquerra Catalana, con lo que la responsabilidad enorme de los causantes de tamaña desgracia sería para inquietar al espíritu menos medroso». .36

El PNV giraba hacia la izquierda. Se justificaba anunciando que lo hacía con afán de captación. Por eso no podría acusarse a los nacionalistas de ir con la izquierda. ${ }^{37}$

Denunciaron los peneuvistas «las coacciones de todas clases efectuadas por los monárquicos, como la nota más destacada de la jornada del 16 de febrero en las dos circunscripciones de Vizcaya. Les sangraba la herida. Perdonarían, pero no olvidarían. ${ }^{38}$

Había fallado Gil Robles en sus cálculos. Había acertado, en cambio, cuando pronosticó que la convocatoria electoral, además de ser un acto abusivo, que excluía del Gobierno a la derecha que aceptaba la República, era un riesgo descontado: las nuevas Cortes serían más ingobernables que las anteriores.

El Frente Popular no podría llevar adelante su programa desde el gobierno. Estaba asediado por unos aliados, la izquierda socialista, que, sin la responsabilidad de compartir el poder, le exigirían ir más allá de lo posible y razonable. Azaña, mostrando valor cívico, había anunciado que era el gobierno el único responsable y ejecutor del programa electoral del Frente Popular. Avisó que restablecería el imperio de la Constitución. ${ }^{39}$

Manuel Portela Valladares, el anterior jefe del Gobierno, además de eludir su deber, cometió el error de consentir que la izquierda triunfara en muchos distritos, montando esa operación fantasma de centro. Creía que las elecciones se ganaban desde el ministerio del Interior. Eso no sucedía ya desde 1933.40

36 «Examen de conciencia en orden al resultado electoral en todo el País Vasco», La Gaceta del Norte, 18 de febrero, 1. Al reproducir estas palabras, el diario nacionalista, negándose incluso a mencionar a Urquijo, lo acusaba de «juego sucio» y de haber comprometido «muy altas cosas y personas», mereciendo la condena de todos. «Hay un hombre que tiene la osadía de escribir», Euzkadi, 20 de febrero, 1 .

${ }^{37}$ Lucio de AraKIL, «Labor proselitista. Objetivos inmediatos», Euzkadi, 9 de enero de 1936, 1.

38 «La elección de Bizkaya, Barkatu, bai; arztu ez, baño», Euzkadi, 18 y 19 de febrero, 2. Engracio de ARANTZADI, «Debemos tenerlo bien en cuenta. Se proyectaba nuestro total exterminio», Euzkadi, 22 de febrero, 1. La Gaceta del Norte, quiso levantar un cadalso donde ajusticiar al nacionalismo. Caricatura de K. «La obra del odio», Euzkadi, 29 de febrero, 1.

39 «El programa del Gobierno Azaña», La Gaceta del Norte, 22 de febrero de 1936, 1.

40 «Portela cede el paso a las izquierdas republicanas, Sin comentarios» y «Mitad y mitad», La Gaceta del Norte, 20 de febrero, 1. 


\section{REACCIÓN ANTE LA VICTORIA}

En esa hora inicial, tras el retorno de las izquierdas al poder, era oportuno reproducir su programa. ${ }^{41}$ Había que aguardar y comprobar si era secundada la actitud conciliadora de Azaña al asumir el poder. No fueron tranquilizadoras las noticias el 22 de febrero. El ayuntamiento de Madrid suprimió el culto en el Colegio de la Paloma y en el de San Ildefonso. Pidió que las Hijas de la Caridad dejaran los centros asistenciales municipales. ${ }^{42}$

Dos oficiales del ejército participaron en una manifestación comunista. Marcelino Domingo pidió a los inspectores de primera enseñanza de toda España un informe para proceder al cierre de los centros de las Congregaciones, allí donde pudiera tomarse la medida. ${ }^{43}$

Esos hechos y otros muchos privaban de confianza al mensaje de Azaña. Sus primeras palabras comenzaban a resultar «una mera habilidad o un buen deseo rápidamente malogrado». ${ }^{44}$ La prensa ministerial se quejaba de que la de la oposición rechazara esas ofertas de convivencia y concordia. ${ }^{45} \mathrm{Y}$ la presentaban ante sus lectores humillada ante el nuevo poder. ${ }^{46}$

Todo el proyecto de un Gobierno de los republicanos, sostenido en las Cortes, fue inviable para asegurar la paz. Porque en las provincias y en los pueblos son las masas las que mandan y las autoridades se hallaban sometidas a comités jacobinos del Frente Popular. Eso abrió la puerta a la pasividad de las autorida-

41 «Un programa que conviene tener muy presente», La Gaceta del Norte, 22 de febrero, 1-2.

42 Pedro Rico y los concejales de la mayoría municipal exigieron el cierre de los cementerios privados para que así la secularización fuera completa. Una «medida de primera necesidad» en una ciudad como Madrid, debieron pensar los ediles repuestos.

43 «Domingo inicia un ataque a fondo contra las Congregaciones religiosas» $\mathrm{y}$ «Marcelino Domingo quiere acelerar el ritmo del laicismo en la enseñanza»,La Gaceta del Norte, 1 y 29 de marzo, 1.

${ }^{44} \mathrm{El}$ programa del gobierno, según su presidente se reducía a tres puntos: reforma fiscal, reforma del ejército y expropiación de los grandes terratenientes. Los campesinos usufructuarían esas fincas y el Estado sería el propietario. «Los primeros síntomas del mal que padecemos», La Gaceta del Norte, 23 de febrero, 1.

45 Caricatura de Gil Robles y Largo Caballero. Diálogo:

-Buenos días, Paquito, ¿cómo estás?

— ¡Mira, José Mari, no vengas provocando...!»

«Provocaciones y Trajes para diputados», La Gaceta del Norte, 24 y 26 de marzo, 1 y 12.

46 «¿Anhelamos que continúe el espectáculo cabileño de fuego que nos presenta ante el mundo civilizado como una excepción bochornosa?...

Contestamos siempre en el tono en que nos hablan.

Y cautos, porque la triste experiencia nos obliga a serlo, porque en el mismo programa electoral que ha convertido el Gobierno en obra, que ha de someter a la discusión del futuro Parlamento, hay temas sobrados no solo para el disentimiento, que eso salta a la vista, sino para el razonado combate esperamos arma en brazo». «En el tono que nos hablan, contestamos», La Gaceta del Norte, 28 de febrero, 12 .

Hispania Sacra, LXII

126, julio-diciembre 2010, 723-756, ISSN: 0018-215-X 
des, de las fuerzas del orden frente a los desmanes, agravios y delitos. Se había entronizado en España, desde la victoria del 16 de febrero «un estado de anarquía sin precedentes». Los ciudadanos pacíficos tenían la sensación de que las leyes no se cumplían, a la vista de los incendios, homicidios, asaltos, agresiones a las fuerzas de orden público...

Los gobiernos, nacidos de esa entelequia llamada Frente Popular, eran débiles. Su mayoría parlamentaria era una ficción. Si un Gobierno se apoyara en una de las facciones beligerantes, fracasaría y, si prevalecía, sería a cuenta de avasallar, sojuzgar, suprimir... Por eso Miguel Maura llamaba al patriotismo. Sin él todo intento de remediar la situación, colmaría el descrédito de la República, «abriendo la compuerta a otra guerra civil política, que vendría a sumarse a la social que hoy nos aflige y nos arruina». ${ }^{47}$

En las manifestaciones del 23 de febrero participaron, junto con toda la izquierda, los nacionalistas del PNV y de ANV. Los condenados por los sucesos de octubre de 1934 salieron a la calle. La izquierda los homenajeaba. Era justo que se readmitiera a los obreros despedidos, con tal de que no fueran represaliados quienes los sustituyeron..$^{48}$

Había que preparar la segunda vuelta. Los resultados fueron decepcionantes desde el punto de vista de la representación parlamentaria:

- contrarrevolucionarios

- nacionalistas

- izquierdas
236296 votos 8 escaños

153246 votos 9 escaños

$165809 \quad 7$ escaños. ${ }^{49}$

${ }^{47}$ Miguel MaURA, «Los comités jacobinos del Frente Popular, el fascismo español y la gravedad de los problemas españoles», El Sol, 21 junio 1936, en Así cayó Alfonso XIII. De una dictadura a otra. Edición de Joaquín Romero Maura, Madrid, Marcial Pons Historia 2007, 524-530.

48 «No se puede lanzar a la miseria a esos obreros», La Gaceta del Norte, 27 de febrero, 1.

${ }^{49}$ La desproporción era mayor, si se excluía Navarra:

- contrarrevolucionarios 124854 votos 1 escaño

- nacionalistas 138627 votos 9 escaños

- izquierdas 130822 votos 7 escaños.

La derecha había ganado 36283 electores, los nacionalistas habían perdido 29371 en las tres provincias y habían obtenido 862 en Navarra. La izquierda creció en 14031 votos. En porcentaje, la situación era así en las tres provincias:

- contrarrevolucionarios $32 \%$

- nacionalistas $\quad 35 \%$

- izquierdas $33 \%$.

Con Navarra la situación se modificaba:

- contrarrevolucionarios $42,50 \%$

- nacionalistas $\quad 27,50 \%$

- izquierdas $\quad 30 \%$ 
El momento era difícil. El gobierno estaba siendo desbordado por sus aliados. ¿Se iba hacia el comunismo, según anunciaba Calvo Sotelo? ${ }^{50}$ El País Vasco era una excepción, de signo positivo. Los vascos se manifestaron como una sociedad pluralista mientras duró la II República. Ninguna fuerza consiguió alzarse con la hegemonía. Ese hecho político expresaba falta de unanimidad respecto a la identidad vasca y sobre su territorio. Fue esta fractura interna su mayor problema para alcanzar su autonomía.

El «problema vasco» no afectaba, por tanto, sólo y principalmente a sus relaciones con el Estado español. Impregnado de tensión, fue un conflicto entre los vascos y en su convivencia. ${ }^{51}$ Para la derecha la sociedad vivía una honda crisis. Se aproximaban horas cruciales. Pintaba un cuadro pesimista, alarmante, que fomentaba la radicalización de las posturas defensivas. La ideología liberal había sido un error y sus instituciones, un fracaso, Ante la presión revolucionaria del proletariado, sólo quedaban «islotes» en un mar de dictaduras, que iban alzándose en todo el mundo.52

Siendo aún Azaña presidente del Gobierno, se le acusó de cerrar los ojos. Esa impresión era falsa..$^{53}$ Mundo Obrero dijo que era la derecha la que promovía los desmanes ${ }^{54}$ El gobierno le hizo caso y comenzó a encarcelar a gentes de esa significación política. «Los gobiernos no pueden dejar en la calle, a merced

${ }^{50}$ La democracia conducía al comunismo Declaraciones de José Calvo Sotelo al $A B C$, reproducidas en El Pueblo Vasco, 28 de febrero de 1936. hay que recordar que Calvo Sotelo y su hermano Leopoldo pertenecieron al Grupo de la «Democracia Cristiana». Vid la excelente biografía de Alfonso BULlón de Mendoza, José Calvo Sotelo, Barcelona, Ariel, 2004.

51 José Luis de la Granja SAInz, Nacionalismo y II República en el País Vasco... 632-634.

52 Los escritores de la derecha rivalizaban en ofrecer «morbosos análisis del momento histórico». Gabriel Plata PARGA, La derecha vasca y la crisis de la democracia española (1931-1936), Bilbao, Bizkaiko Foru Aldundia=Diputación Foral de Bizkaia 1991, 93-94 y 98-100.Un estudio comparado, Conflicto político, democracia y dictadura. Portugal y España en la década de 1930, Mercedes GuTiÉrRez SÁnchez y Diego Palacios Cerezales, (editores), Madrid, Centro de Estudios Políticos y Constitucionales 2007.

53 «Vamos cuesta abajo por la anarquía persistente en algunas provincias, por la taimada deslealtad política de los socialistas en muchas partes, por las brutalidades de unos y otros, por la incapacidad de las autoridades, por los disparates que el Frente Popular está haciendo casi en todos los pueblos, por los despropósitos que empiezan a decir algunos diputados republicanos de la mayoría». Escribe Azaña el 17 de marzo, Santos Juliá, DíAz, Manuel Azaña: una biografía política: del Ateneo al Palacio Nacional, Madrid, Alianza, 1991, 470.

54 «Las noticias de provincias, dice el señor Azaña, acusan tranquilidad», La Gaceta del Norte, 12 de marzo, 7. Los hechos lo desmentían. Amós Salvador, ministro de la Gobernación, tuvo que reconocer que había desórdenes e inseguridad en la calle. Una lista de los ataques contra la Iglesia entre el 17 de febrero y el 5 de mayo, José Pla, Historia de la Segunda República española, tomo IV, Barcelona, Destino, 1940. pp. 290-300, 311-323, 342-357, 375-385 y 410-322. Hay una reedición, La Segunda República Española: una crónica, 1931-1936, edición de Xavier Pericay, prólogo de Valentí Puig, traducción de Jorge Rodríguez Hidalgo, Barcelona, Destino, 2006, 1842 pp.

Hispania Sacra, LXII

126, julio-diciembre 2010, 723-756, ISSN: 0018-215-X 
de las turbas, el principio de autoridad», decía El Sol el 13 de marzo. ${ }^{55}$ La falta de garantías afectó enseguida al Parlamento.

Lamentaba La Gaceta del Norte el «furor iconoclasta» que parecía reducir a destrucción toda reivindicación política. ${ }^{56}$ El Gobierno debía seguir en su puesto. Representaba no el odio ciego, sino «los intereses comunes de todos los ciudadanos, la prosperidad pública, el bien de toda la nación, que no podía ser maltratada y conducida a la bancarrota».

Se puso al lado de la autoridad, de su legitimación de ejercicio y de origen. Era el deber moral de un diario «netamente católico e independiente». Confiaba en el futuro. Había que librarse de las «reacciones meramente negativas». No todo estaba pedido. Por trances semejantes y aun peores pasaron otros pueblos. Existía un ejemplo a seguir: Francia. Allí el catolicismo estaba penetrando en la sociedad y rivalizaba con la izquierda en la aceptación por parte de la clase obrera. Lo había reconocido el mismo Léon Blum. ${ }^{57}$ Los católicos asumirán ahora su responsabilidad ante los desafíos políticos del país. ${ }^{58}$

\section{NACIONALISTAS Y GUERRA CIVIL}

Pasados los primeros días de la guerra, el miedo a lo que podría suceder marcó la posición de muchos nacionalistas en la zona controlada por los sublevados, y en Guipúzcoa y Vizcaya, leales a la República. En el primer caso, actuaron movidos por la necesidad de proteger a su familia. En el segundo, busca-

\footnotetext{
55 «Anteanoche ocurrieron en Madrid graves sucesos», La Gaceta del Norte, 15 de marzo, 4. la protesta de la Santa Sede y el silencio del Gobierno ante las notas presentadas por la nunciatura, desde el 14 de marzo de 1936, Vicente CÁrCel OrTí, Pío XI entre la República y Franco, Madrid, Biblioteca de Autores Cristianos, 2008, pp. 614-743.

${ }^{56}$ Puños cerrados, todos rojos y uno en gris. Texto de la caricatura: «iPido la palabra para una cuestión de orden!», «Parlamentarismo», La Gaceta del Norte, 25 de marzo, 1.

57 «El signo de la destrucción», La Gaceta del Norte, 18 de marzo, 12. El editorial terminaba con una cita del político francés. En el acercamiento permanente al pueblo y a sus aspiraciones cifraba el porvenir de la Iglesia. En España tenía la ventaja de que la descristianización no había avanzado tanto como en la Francia de la III República. «El éxito de una cruzada religiosa», La Gaceta del Norte, 26 de marzo, 1. Sobre la identificación católicos y derecha y sobre los signos de elajamiento de la Iglesia, en la diócesis de Vitoria, Joaquín PeREA, El modelo de Iglesia subyacente en la pastoral del clero vasco (1918-1936), Bilbao, Instituto Diocesano de Pastoral-Desclée de Brouwer, 1991, 314-323. La descristianización en las zonas obrera es anterior a 1931. Vid. los informes de los arciprestes en 1922, ibidem 298-299.

${ }^{58}$ No a los gobernantes que se dejaban arrastrar. Era preciso situar al pueblo «en racionales condiciones de ejercer sus derechos sin menoscabo de la prosperidad colectiva». «La educación de las masas», La Gaceta del Norte, 31 de marzo, 1.
} 
ban defender el orden. ${ }^{59}$ Como aseguró Monzón: ese deber les impidió obedecer la pastoral de los obispos de Pamplona y de Vitoria. ${ }^{60}$

Igual sucedió con la llamada de Pío XI el 14 de septiembre de 1936: había que utilizar medios lícitos en la defensa de la religión. ${ }^{61}$

La posición de la Iglesia ante el movimiento militar pudo estar afectada por la experiencia del octubre de 1934. Hay que examinar lo que sucedió entonces. Hubo asesinatos de sacerdotes y religiosos, incendio de templos y de otros edificios de la Iglesia, ataques a la propiedad... Era síntoma del significado que la revolución tendría en España. ${ }^{62}$ Eso explica la preocupación de la Santa Sede ante la opción del nacionalismo vasco ante esos sucesos. ${ }^{63}$

Una persona moderada como Vidal i Barraquer, implicó a Azaña en el alzamiento revolucionario contra el Gobierno que formó Alejandro Lerroux el 4 de octubre de $1934 .{ }^{64}$ Calificó estos sucesos como un «alzamiento armado formidable», especialmente en Asturias, Galicia y Cataluña. El horizonte era la «dictadura del proletariado». .5

${ }^{59}$ Cuando se habló de la incorporación de un nacionalista al gobierno presidido por Largo Caballero, Manuel de Irujo puso estas condiciones: respeto a la religión y a la propiedad, gobierno autónomo vasco y que las milicias, los gudaris, incluso en tiempo de guerra, sirvieran únicamente en territorio de Euzkadi. Ceferino de Jemein, 18 de julio de 1936. El nacionalismo vasco y a sublevación militar en Euzkadi, Bilbao, Alderdi, s.f [986].

${ }^{60}$ Sobre la postura del obispo de Vitoria, Fernando GARCía dE CORTÁZAR, «Mateo Múgica, la Iglesia y la Guerra Civil en el país Vasco», Letras de Deusto 16 (1986) 5-32.

${ }^{61}$ Estos comentarios, Fernando de MEER, El Partido Nacionalista Vasco ante la Guerra de España (1936-1937), Pamplona, Eunsa, 1992, 89-99, 111-112 y 138-148.

${ }^{62}$ Se habían cometido crímenes horrendos. Se habían destruido propiedades, torturado y asesinado a las personas, incluidos los niños. Habían asesinado a sacerdotes y religiosos. Esos mismos crímenes se produjeron en Oviedo. Entre el clero, en la ciudad, se contaban más de 40 asesinados. Algunos fueron quemados vivos. 6982 y 7012 Tedeschini-Pacelli 17 y 25 octubre 1934, ASV Arch.Nunz.Madrid 912 200-203 y 195-198. En su primera comunicación, Tedeschini insistió en la proclamación de independencia hecha por Companys. Tc 76 Tedeschini-Pacelli, 7 octubre 1934. ibidem 900550 verso.

63 Tedeschini-Mateo Múgica, 10 octubre 1934 y respuesta de, 17 octubre, ASV Arch.Nunz.Madrid 913621 y 604-608. Acusaciones contra los nacionalistas y una denuncia de su complicidad con la izquierda en los sucesos de octubre de 1934, tres cartas reservadas del Conde de Villafranca de Gaytán a Tedeschini, 7, 14 y 24 de julio de 1935, ibidem 913 635-638.

${ }^{64}$ El nuevo Gobierno ofrecía «una mayor garantía de estabilidad y de comprensión» para los intereses de la Iglesia, decía Vidal i Barraquer a Pizzardo. Vidal i Barraquer-Pizzardo, 8 octubre, ASV AES Spagna IV 856/ 240 5-7. Sobre la formación del nuevo Gobierno y su significado, tc 76 Tedeschini-cardenal Pacelli, 9 octubre 1934, ibidem 4. Sobre los preparativos para hacer la revolución, 6944 Tedeschini-cardenal Pacelli, 21 septiembre, ibidem 10-11. «En la Casa del Pueblo de Madrid se descubre un arsenal de armas, bombas y cartucho», El Debate 15 septiembre, 1. «Don Horacio Echevarrieta ingresó anoche en la cárcel por el contrabando de armas», El Debate, 16 septiembre, 1. «El laboratorio socialista de explosivos en la Ciudad Lineal», El Debate 20 septiembre, 1.

65 En Morell, a pocos Kms. de Tarragona, los revolucionarios asaltaron el templo parroquial, lo destruyeron, quedando sólo las paredes y la bóveda. Quemaron las imágenes y ornamentos. Dispararon

Hispania Sacra, LXII

126, julio-diciembre 2010, 723-756, ISSN: 0018-215-X 
La referencia a Azaña era obligada, porque estaban en el movimiento revolucionario todos los «que monopolizaron el poder dos años. Había que parar «la evolución moderadora de la República». En el Gobierno de Alejandro Lerroux, hubo previsión, energía y acierto. Había controlado la situación y los revolucionarios solo consiguieron mantener focos aislados. Fue una medida acertada declarar el estado de guerra.

Era un movimiento para alcanzar por la violencia el poder, ahora en manos del centro y de la derecha, que habían llegado a él por medios legales. ${ }^{66}$

La revolución contaba con las armas. Tenía el apoyo sindical de la UGT y de la CNT. Era un estallido preparado y anunciado. Lluis Companys pedía a los catalanes que estuvieran alerta. En Barcelona había esos días políticos importantes de Madrid.

En Asturias había muchas señales de que en España se preparaba el mayor movimiento revolucionario conocido hasta entonces. Tedeschini considera providencial que el ejército se hubiera mantenido leal al poder civil. La incógnita sobre él se despejó en esos momentos.

Al principio no se conocían ataques a la Iglesia, a las personas y a las cosas religiosas. Nada se sabía de lo que estaba pasando en Asturias. ${ }^{67}$

Pasado un mes, a la vista de las informaciones, de los relatos y de las fotografías, se calificaban los sucesos de Asturias como de «revolución soviética». ${ }^{68}$ El SOMA, de la UGT, fue capaz de poner en pie un verdadero ejército. Desde el punto de vista político, el militar asturiano, José María Fernández Ladreda y Menéndez Valdés, juzgó «un desastre» la actuación del Gobierno. ${ }^{69}$

contra el cura, que se asomó al balcón para ver qué pasaba. Le atravesaron un pulmón. Estaba hospitalizado y en grave estado.

66 Vidal i Barraquer-cardenal Pacelli, y Vidal i Barraquer-Pizzardo, 8 octubre 1934, Arxiu Vidal $i$ Barraquer. Església i Estat durant la Segona República Espanyola 1931-1936. Textos en la llengua original, Edició a cura de M. Batllori i V. M. Arbeloa, IV 10 d'octubre de 1933-18 juliol 1936, $1^{\mathrm{a}}$ i $2^{\mathrm{a}}$ Part, Monestir de Montserrat 1986, 559-570. El cardenal Pacelli pasó por Barcelona el 26 de septiembre, camino de Buenos Aires y regresó el 1 de noviembre. El comentario sobre Morell, Vidal i Barraquer-Alcalá Zamora, 12 octubre, ibidem 577-578.

${ }^{67}$ Sobre la restauración de los edificios destruidos, 7109 Tedeschini-Cardenal Pacelli, 20 diciembre 1934, ASV AES Spagna IV 856/240 39. La lista de los edificios, 7360, 3 abril 1935, ibidem. 72. La relación, ordenada por Justo Echeguren y hecha por un arquitecto, «Daños sufridos por las iglesias, capilla y casas rectorales de la diócesis de Oviedo, a causa de los sucsos revolucionarios de octubre. Memorias. Valoraciones. Arquitecto Diocesano, Enrique R. Bustelo», Oviedo diciembre 1934. Copia ibidem fascículos 241 y 242.

68 Octubre 1934. Cincuenta años para la reflexión, Madrid, Siglo XXI, 1985. David RuIz, Vid. David RuIz, Insurrección defensiva y revolución obrera. El octubre español de 1934, Barcelona, Labor, 1988, y Octubre de 1934, Madrid, Síntesis, 2008. Octubre 1934. Cincuenta años para la reflexión, Madrid, Siglo XXI, 1985.

697026 Tedeschini-cardenal Pacelli, 8 noviembre, ASV AES Spagna IV 856/240 32. 
Existían un imaginario y una memoria de los sucesos de cien años antes. En 1834 , los templos fueron saqueados y profanados. Los religiosos, dispersos. Hubo actos de canibalismo, arrancaron los ojos a religiosos moribundos, desnudaron sus cadáveres, se repartieron sus vestidos. «La tea y el puñal» abrieron entonces un vado infranqueable entre las dos España, una, de víctimas y otra, de verdugos. Aquella guerra religiosa fue de exterminio asolamiento, de degüello y represalia. ${ }^{70}$

Azaña tuvo otra experiencia e interpretó los sucesos de otro modo, pero vio en ellos un mal presagio. HayCreyó que las dos claves eran el miedo a la fuerza creciente de la reacción y la radicalización de las bases del PSOE, que sus dirigentes no pudieron controlar. Se trataba de un asalto al poder para «invalidar todo lo que la República pudiera tener de reformista, más que de revolucionaria, en el orden social».

Rivas Cherif atribuye la revolución a la entrada de José María Gil Robles en el Gobierno. Lo califica de «diputado genuino de los jesuitas». ${ }^{71}$ Recuerda que Azaña sostuvo el 28 de marzo de 1932 que la República era para todos, pero debía ser gobernada solo por los republicanos. Los diputados de la CEDA no habían jurado la Constitución.

Estaba Azaña en Barcelona cuando se produjo el levantamiento contra el Gobierno. Le irritó que lo incluyeran entre los dirigentes de esa conspiración, porque su norma de conducta política era el respeto al Poder Público. No compartía el extremismo de los catalanistas ni la conducta imprudente de los socialistas.

Puesto en libertad el 28 de diciembre, se quedó unos días en Barcelona. Vino luego una represión política. En el parlamento, había una invencible mayoría «incivil». La falta de equidad entre el trato dado a los sublevados en agosto de 1932 y el que estaban dando a los revolucionarios de octubre, provocó una respuesta ciudadana que llevaría a la victoria electoral de la izquierda en febrero de 1936.72

Se ofrecían en diciembre de 1933 a la derecha dos políticas. Una, exterminar al adversario, con una revolución, que acabara e n u nuevo Estado, acabando con el sistema liberal parlamentario. La otra, convivir con esas fuerzas adversas operando su desarme moral mediante reformas, que implicaran avances en la

\footnotetext{
${ }^{70}$ Francisco PeIRó, El problema religioso-moral en España, Madrid, Razón y Fe 1936, 38. Peiró vincula a quienes asesinaron religiosos y quemaron sus iglesias y conventos con quienes se beneficiaron de la desamortización, los afrancesados, los jansenistas.

${ }^{71}$ Sobre el error de José María Gil Robles; Miguel MAURA, «El deslinde de las Derechas» discurso en las Cortes, 16 de noviembre 1934, Así cayó Alfonso XIII... 493-497.

72 Cipriano de Rivas Cherif, Retrato de un desconocido. Vida de Manuel Azaña (2), Barcelona, Grijalbo 1981, 293-305. El libro fue escrito entre 1941-1943, mientras el autor estaba en la cárcel. La primera edición en esta editorial es de 1979.
}

Hispania Sacra, LXII

126, julio-diciembre 2010, 723-756, ISSN: 0018-215-X 
legislación social y una más justa distribución de la riqueza. Para la primera había el apoyo de una masa que apoyó a los partidos de derecha. Para la segunda, se necesitaba espíritu de sacrificio y cualidades en sus jefes. Era una apuesta arriesgada, pero aseguraba la paz interior y «normalizaba para muchos años la vida de España»

No se siguió ni una ni otra. Se provocó a las organizaciones obreras, a los republicanos burgueses, resucitando prácticas caciquiles. Se retaba a las organizaciones obreras a que llevasen adelante sus amenazas de revolución. Y esto se hacía en las Cortes. El Parlamento se consagró a derribar la obra de las Cortes Constituyentes. Se jactaron de haber provocado la revuelta para aplastarla. No fue así, porque «ni la vencieron en su espíritu ni en su raíz, ni siquiera supieron sancionarla con justicia y castigar a los culpables con equidad». ${ }^{73}$

Volvamos desde la imaginación y desde la interpretación a los acontecimientos de ese verano de 1936. Mucho de lo dicho sobre los obispos, la Santa Sede, los católicos en esas primeras semanas posteriores al 18 de julio de 1936, es una operación de propaganda. Lo fue también lo dicho desde el mundo católico. ${ }^{74}$ En el Vaticano ¿estaban bien informados de lo que estaba pasando ${ }^{75} \mathrm{~Pa}$ rece que no. Eso explica su postura reservada y expectante. Pío XI habló del peligro del comunismo, pero confiaba en que Santiago Casares Quiroga y Azaña lograran vencerlo. Lo mismo creía Luis de Zulueta, embajador ante la Santa Sede. Se necesitaba tiempo, pero se resolvería la cuestión religiosa, como había sucedido en Francia.

A mitad de septiembre de 1936 tenían los nacionalistas conciencia de la dimensión del conflicto. Como en 1934, también ahora los jelkides habían coincido con «otros sectores políticos y sociales» distantes de sus planteamientos confesionales. Urgía reafirmarlos ante los conjurados contra la libertad del pueblo vasco y los que llamaban apóstatas a los nacionalistas. ${ }^{76}$ Eran los otros quie-

${ }^{73}$ Miguel MAUra, «Una política suicida», El Sol, 18 junio 1936, y «Subversión y definitivo desprestigio del sistema parlamentario», El Sol, 20 junio 1936, en Así cayó Alfonso XIII... 510-518 y $522-$ 524.

74 Un caso ejemplar de quienes aceptan la propaganda y se ajustan a ella, Ramón ComAs, Isidro Gomá, Françes Vidal i Barraquer: dos visiones antagónicas de la Iglesia española en 1939, Salamanca, Sígueme 1977. La edición de los archivos de los dos cardenales y otra documentación existente en el Archivo Vaticano reduce mucho las diferencias entre el «Cardenal de la Pau» y el cardenal de la Cruzada. Vid. Ramón Muntanyola i Llorach, Vidal i Barraquer. Cardenal de la Pau, Barcelona, Editorial estela 1969 y Publications de l'Abadia de Montserrat 1976.

75 El 29 de agosto de 1936, Jacques Truelle, encargado de negocios ante la Santa Sede, informaba a Yvon Delbos, ministro de Asuntos Exteriores que el cardenal Pacelli consideraba excepcional la situación del cardenal Vidal y Barraquer y deseaba que los obispos no abandonaran sus diócesis. Fernando DE MEER, El Partido Nacionalista Vasco... 124-125.

76 «Por lo visto, el cristianismo ha de consistir en salir armados de todas las más mortíferas armas por esos campos a devastarlos y despanzurrar gentes y asomarse a esas ciudades mártires a sembrar a 
nes, hipócritamente, habían conculcado, con su adhesión a la rebelión, todos los principios que decían profesar hasta entonces. Seguían los nacionalistas su lema de siempre. ${ }^{77}$

Las guerras del siglo XIX habían cerrado un ciclo. La burguesía despojó a la Iglesia de sus bienes y exclaustró a sus frailes. Amenazada por el pueblo, que no soportaba su situación de hambre, se refugiaba ahora en la Iglesia, para hallar en ella amparo para sus bienes y sus vidas. Quería que el catolicismo ametrallara con sus sanciones espirituales a los que gemían en un régimen social y económico que poco difería de la esclavitud.

Dominada por el poder de los ricos muchos años, sus enemigos habían convencido al pueblo de que «la religión no era más que adulación de la riqueza y menosprecio de los pobres». El pueblo español consideraba una misma cosa capitalismo, cesarismo, fascismo y catolicismo. Los vascos, en cambio, respetaban a los sacerdotes y dejaban en pie los templos. ${ }^{78}$

El presidente del Gobierno de Euzkadi revalidó la tesis de que se trataba de una guerra contra el fascismo. ${ }^{79}$ Nada tenía de religiosa. ${ }^{80}$ Era un conflicto entre

voleo la desolación sobre ellas». El cristianismo era contrario a toda forma de esclavitud. Lucio de ARAKIL, «Nuestra consecuencia», Euzkadi, 19 de septiembre de 1936, 1.

77 «El nacionalismo, en la lucha», Euzkadi, 25 de septiembre, 1.

78 «Por convenir a sus negocios, por asegurar beneficios injustos a capitales amontonados muchas veces suciamente, $\mathrm{y}$ también por no perder contacto con las gentes adineradas, se ha colocado por ahí a la Iglesia al servicio de la riqueza. Eso, al menos, han creído ver las muchedumbres. Y en los choques de los elementos populares con la plutocracia han creído ver a la religión aliada con ésta en su daño. Al seguir el nacionalismo vasco hoy su programa social de siempre, el de los Papas, a costa de tanto dolor, verán los obreros, que las organizaciones sinceramente religiosas, como la nacionalista vasca están, por serlo, con el pueblo. Que la democracia no está reñida con el catolicismo». Miguel de BEOTEGUI, «Templos vascos intactos, Lección sangrienta» y «El capitalismo soberbio y sórdido es la causa del hundimiento de la plutocracia en Euzkadi», Euzkadi, 19 de octubre y 16 y 27 de diciembre, 1. La cita pertenece al segundo. «¿Una cruzada? Catolicismo hipócrita apoyado por mahometanos y cismáticos, no; catolicismo patriótico fundado en las encíclicas, sí. Al pueblo vasco no se le ha permitido desarrollar una obra social justa y cristiana», Euzkadi, 22 de diciembre, 1.

79 «Las promesas de la revolución no eran las mismas en cada bando [comunista y fascista]; pero los regímenes son comparables, casi idénticos después de algunos años de existencia... Unos fusilaron a los burgueses, otros han aplastado a los obreros, pero unos y otros inventaron el gobierno del partido único y la mentira de la unidad del pueblo». La denuncia de esta concentración del enemigo como «fascista», en François FURET, El pasado de una ilusión. Ensayo sobre la idea comunista en el siglo XX, Madrid, Fondo de Cultura Económica, 1995, 209 y 242, 272, 296, 299, 305, 339. Furet comienza su libro desmontando la identificación capitalismo-democracia-burguesía y denunciando como raíz de la revolución el desconocimiento y la pérdida de la idea de bien común, ibidem 26 y 44.

${ }^{80}$ Esta posición hizo que el PNV aceptara entrar en el Gobierno de Largo Caballero el 26 de septiembre de 1936 y aceptar la cartera de justicia en el formado por Juan Negrín el 17 de mayo de 1937. José M. Margenat Peralta, «Manuel de Irujo: la política religiosa de los gobiernos de la república en la guerra civil (1936-1939)», Cuadernos de Historia Moderna y Contemporánea, 4, 1983, 175-193.

Hispania Sacra, LXII

126, julio-diciembre 2010, 723-756, ISSN: 0018-215-X 
«las legítimas ansias de justicia social y un conservadurismo caduco, aferrado a sus privilegios». ${ }^{81}$ Combatían los vascos contra el autoritarismo de las derechas españolas, que jamás podrán justificar su rebelión. ${ }^{82}$ Los nacionales llamaban a su sublevación una cruzada. ${ }^{83}$ El Cardenal Isidro Gomá dijo que era «una «desgraciada contienda». ${ }^{84}$ Los nacionalistas vascos lo calificaron como una agresión cometida por unas gentes, que podrían agruparse bajo la designación de «Fascio-Regalista». Su concepto de Estado impedía seguir los dictados de la conciencia. Eso había sucedido ya con el obispo de Vitoria, Mateo Múgica, desterrado y objeto de calumnias ${ }^{85}$ Los católicos vascos podían creer, sin dudarlo un instante, que «sus enemigos no estaban con Jesucristo».86

81 «Nuestro pueblo ante la sublevación fascista», Euzkadi, 23 de diciembre, 1 y 3. Discurso de José Antonio de Aguirre radiado y dirigido a todo el mundo. El cardenal Isidro Gomá creyó su deber responder a este discurso. Respuesta obligada: carta abierta al Sr. D. José Antonio Aguirre por el Emmo. Sr. Dr. D. Isidro Gomá Tomás, cardenal Arzobispo de Toledo, Gráficas Pamplona, Bescansa 1937. Puede leerse en http://www.gipuzkoakultura.net/euskera/ediciones/atzo/1937/index.htm

Le replicó el 9 de marzo Aguirre. Vid la edición de esta carta en Fernando DE MEER LECHA-MARZO, «Una carta de José Antonio Aguirre al cardenal Gomá (9 de marzo de 1937). nota documental», Boletín de la Real Academia de la Historia, 184/3 (1987) 521-552.

82 Miguel de BeOtegui, «Insurrección», Euzkadi, 21 de octubre, 1.

${ }^{83}$ El 29 de julio e 1936, Miguel Cabanellas, como presidente del Comité de Defensa Nacional, se dirigió al cardenal Pacelli. Le comunicó que estaba bajo su control la mayor parte del territorio. Le preguntó si aceptaría la presencia de un agente confidencial. Afirmó que «el movimiento nacional» era una «cruzada religiosa y un rescate de la patria frente a la tiranía de Moscú». Recordó estas palabras el cardenal Nicola Canali, en la sesión de la Congregazione degli Affari Ecclesiastici Straordinari, del 17 de diciembre de 1936. El 31 de julio de 1937, Franco dijo a Ildebrando Antoniutti que el Movimiento, además de militar y político, era de carácter religioso: una cruzada para hacer revivir entre los españoles las antiguas tradiciones católicas. ASV AES «Rapporti delle sessioni» 95, Sessione 1372. Spagna. Provvedimenti in sequito alla Guerra Civile. Dicembre 1936, 18, en Vicente Cárcel Ortí, Pío XI entre la República...239, 259 y 308.

${ }^{84}$ Archivo Gomá. Documentos de la Guerra Civil. 5 abril-mayo 1937, edición de José Andrés-Gallego y Antón, M. Pazos, Madrid, CSIC, 2003, 63. Vid. Luisa RodRíGUEZ AISA, El cardenal Gomá y la guerra de España. Aspectos de la gestión pública del Primado 1936-1939. Madrid 1981, CSIC, 420425 .

85 Mateo MúgICA, Imperativo de mi conciencia. Carta abierta al presbítero D. José Miguel de Barandiarán, París 1945. Un estudio de su figura como obispo, Carlos MoredA DE LECEA, Don Mateo Múgica Urrestarazu (Antecedentes, pontificado en Pamplona y algunos aspectos de su pontificado en Vitoria), Pamplona, Eunsa1992.

86 Mendikimu, «¿Guerra cristiana?», Euzkadi, 24 de noviembre, 1-2.

La fascinación del fascismo sobre algunos sectores de la Iglesia puede verse en la euforia despertada por la firma de los Pactos Lateranenses y el Concordato entre la Santa Sede e Italia. El acercamiento de algunos sectores católicos al nazismo, Martino PATTI, Chiesa Cattolica tedesca e Terzo Reich (1933-1934). Il caso di M. Schmaus, J. Ortz, F. Taeschner, Francia Von Papen, Prefazione di Daniele Menozzi, Brescia, Morcelliana, 2008, 364. Patti hace la introducción y luego reproduce textos de los autores en los que revelan su apertura al nacionalsocialismo y sus coincidencias con él. Todos aparecieron en la colección Kirche und Reich, editada en Münster. Se publicaron entre el invierno de 1933 y la primavera de 1934. Es decir, vísperas del giro que inicia el nazismo a partir de la segunda mitad de este año. 
El discurso de Pío XI a los españoles el 14 de septiembre de 1936 fue una seria advertencia a quienes cooperaban con «las fuerzas subversivas» distinguiendo en ellas entre ideología y acción política. El PNV dejó claro que no era oportuno ni conveniente para derrotar el fascismo un gobierno «marcadamente marxista». Gracias a esa expresión ambigua, pactaron con políticos que se mantuvieron neutrales ante quienes persiguieron a la Iglesia. Esa colaboración creó a los nacionalistas un grave problema moral que quisieron consultar con Roma.

Pío XI tampoco fue muy explícito. Se puso al lado de quienes «han asumido la difícil y peligrosa tarea de defender y restaurar los derechos y el honor de Dios y de la Religión, que es como decir los derechos y la dignidad de las conciencias, la condición primera y la base segura de todo humano y civil bienestar». La dificultad y el riesgo residían, según el Papa, en los excesos que podrían cometerse bajo la inspiración de intenciones no siempre rectas, sino viciadas por intereses egoístas o de partido.

A finales de octubre de 1936, Mateo Múgica, exiliado por los militares, redactaba un informe para el Papa. Se defendió de las acusaciones contra él y analizó la trayectoria del PNV, descalificando su adhesión a las izquierdas. Los responsables de esa traición a sus ideales fueron los dirigentes, ${ }^{87}$ divididos entre ellos pocas semanas después. ${ }^{8}$

Mateo Múgica informó el 16 de noviembre de 1936 sobre la situación de la Iglesia y las ayudas necesarias. Habían sido destruidas en toda España 9938 parroquias. Más de la mitad en las provincias eclesiástica de Tarragona, Toledo y Burgos. Además de los edificios, se habían quemado ornamentos, objetos y libros sagrados ${ }^{89}$

\footnotetext{
87 «Lícito (el nacionalismo) en sus aspiraciones legítimas de lograr sus libertades antiguas, sus fueros respetados por los Reyes más poderosos que tuvo España. De tumbo en tumbo, por falta de cabeza de sus dirigentes, han caído en contubernios vergonzosos, con izquierdistas y últimamente, en pacto con los de Frente Popular, llegando en su ceguera a dar un ministro al Gobierno de Largo Caballero y formar un ridículo Gobierno de la República Vasca. ¡Incalificable! Cómico, si no fuera trágico». Fernando DE MEer, El Partido nacionalista..., 157-158 y 186-192.

${ }^{88}$ El 16 de enero de 1937, los servicios de información de la Comandancia Militar de Bidasoa redactaron un informe, subrayando estas diferencias. Los «viejos» consideraban que la solución pasaba por una persona: Julio Jáuregui. Los «jóvenes», que estaban mezclando el tradicionalismo jelkide con elementos liberales, esperaban que Vizcaya se salvara gracias a la intervención de la Sociedad de Naciones, donde esperaban pensaban contar con la ayuda de Inglaterra. Frente a Garmendia y otros, Leizaola, Monzón y Aguirre, confiando en las promesas de Prieto, se oponían a negociar con los nacionales. Los leales a la República usaban el catolicismo para criticar a Franco. Querían conservar Vizcaya libre del contagio de comunistas y sindicalistas. El Partido nacionalista..., 357 y 317.

89 Copia mecanografiada, 26 noviembre 1936, ASV AES Spagna IV 889/265 41-42. Antonio Montero ha hablado del «martirio de las cosas». Este concepto apareció ya en 1937. José PALOMERo PÁRAMO «Estudios, propaganda y reconstrucción del patrimonio artístico tras los desastres de la incivil guerra española: irradiación del modelo Sevilla (1936-1937)», La Iglesia en tiempos difíciles. Actas del
}

Hispania Sacra, LXII

126, julio-diciembre 2010, 723-756, ISSN: 0018-215-X 
Tras abandonar Madrid, Silvio Sericano, encargado de negocios redactó un extenso informe sobre a situación en la ciudad desde el inicio de la revolución hasta su salida. Desde el 19 de julio a 3 de noviembre, por medio de telegramas cifrados había informado a la Santa Sede.

En la tarde del 18 de julio, el director de El Debate envió un redactor a la nunciatura para decirle que se refugiara en una embajada, descartando las de Alemania Italia y Portugal, porque nada aseguraba que no fueran asaltadas. Decidió seguir en su puesto. La noche del 18 salió de Madrid su obispo, Leopoldo Eijo y Garay..$^{90}$

El 19, armadas las milicias socialistas y comunistas, sembraron el terror por las calles. ${ }^{91}$ Por la tarde se inició la quema de templos. ${ }^{92}$ En la mañana del 20 temió que incendiasen la nunciatura, como había sucedido el día anterior con la cercana parroquia de San Andrés..$^{93}$ La toma del Cuartel de Montaña fue un hecho sangriento en el que intervinieron aviones leales a la República.

En esos primeros días, 20 iglesias incendiadas, incluida la catedral de San isidro, y todas las demás saqueadas. Se buscaba a sacerdotes, religiosos y religiosas a los que se creían en posesión de dinero, para saquearlos. Muchos

XIX Simposio de la Historia de la Iglesia en España y América, Colección Estudios. Actas, Córdoba 2009, 156-172. El inventario de lo destruido desde enero hasta hasta septiembre de 1936.

90 Para la situación de la Iglesia en Madrid estos años, KoDASVER, Medio siglo de vida religiosa matritense. 1913-1963, Madrid, Aldus 1967. José Luis Alfaya CAMACHO, La diócesis de Madrid-Alcalá durante la guerra civil: 1936-1939. Pamplona, 1987 (tesis doctoral defendida el 1 de junio de 1987 en Facultad de Teología de la Universidad de Navarra y su libro, Como un río de fuego. Madrid 1936, Madrid, Ediciones Internacionales Universitarias 1999. Javier CERVERA GIL, Madrid en guerra, la ciudad clandestina, 1936-1939, Madrid, Alianza Editorial, 1998. José Luis GonzÁLEz Gullón, Los sacerdotes durante la Segunda República en Madrid, texto resumen de su tesis, aún inédito. Cortesía del autor.

${ }^{91}$ Sobre las expectativas revolucionarias y la movilización de la izquierda en Madrid los años inmediatos, Sandra Souto Kustrín, $Y$ ¿Madrid? ¿Qué hace Madrid? Movimiento revolucionario y acción colectiva (1933-1936), Madrid, Siglo Veintiuno de España Editores 2004. Hubo semejanza con los sucesos de Viena, puesta de relieve hace años por Palacio Atard. Vid. Sandra Souto Kustrín «De la paramilitarización al fracaso: las insurrecciones socialistas de 1934 en Viena y Madrid», Pasado y memoria. Revista de Historia Contemporánea 2 (2002) 5-55, edición digital.

${ }_{92}$ Sobre los atentados contra los edificios de la Iglesia y las coacciones al clero, protestaron Tedeschini y Silvio Sericano, cuando quedó como encarado de negocios. Vid. Vicente CÁrCEL, Pío XI entre la República y Franco... 647-691. Un estudio sobre lo sucedido desde la llegada de la República, José Ramón HeRnÁNDEZ FigueIREdo,Destrucción del patrimonio religioso en la II República (1931-1936). A la luz de los informes inéditos del Archivo Secreto Vaticano, Madrid, Biblioteca de Autores Cristianos, 2009.

${ }^{93}$ Los actos delictivos y su impunidad eran una evidencia desde que se inició la campaña electoral. Ese proceso iba degenerando y a más. Temía Miguel Maura que, colmado el descrédito de la República, se abriera «la compuerta a otra guerra civil política, que vendría a sumarse a la social que hoy nos aflige y nos arruina». «Los comités jacobinos del Frente Popular, el fascismo español y la gravedad de los problemas españoles», El Sol, 21 junio 1936, en Así cayó Alfonso XII... 524-530. 
sacerdotes fueron asesinados. Los demás estaban dispersos y ocultos ${ }^{94} \mathrm{El} 21$ de julio presentó una nota de protesta ante Augusto Barcia, ministro de Estado. No hubo respuesta oficial.

Comenzaron luego los asesinatos de civiles. Las milicias sindicales y de los dos partidos obreros parecían buscar en el botín su propio beneficio. Los registros se hacían calle por calle y casa a casa. La mayoría de los detenidos fueron asesinados en la Casa de Campo o en los cementerios de la ciudad. Cuando salió el 5 de noviembre había unos 2000 presos políticos. Toda la riqueza pública y privada pasó al control de las organizaciones rojas.

El Gobierno era incapaz de intervenir. ${ }^{95}$ Hubo matanzas colectivas de presos que estaban bajo su custodia. Estas iniquidades, cometidas en la zona republicana, agravaban el comportamiento de los vascos. Era intolerable.

Uno de los asuntos más delicados fue asegurar el derecho de asilo. A comienzos de noviembre había unos 2000 protegidos por las legaciones extranjeras en Madrid. ${ }^{96}$ Los pasos dados por el cuerpo diplomático para humanizar la guerra fueron inútiles. Los condenados eran ejecutados inmediatamente. Los otros, eran puestos en la calle de noche, mientras había «estado de sitio». Caían en manos de las milicias que los asesinaban en el acto. ${ }^{97}$

\section{«UNO DE LOS ASUNTOS MÁS DELICADOS»}

Tras la caída de Bilbao ${ }^{98}$ y bajo el «Ejército de Ocupación», fueron encausados algunos sacerdotes seculares y religiosos. En muchos casos los denuncia-

${ }^{94}$ La situación del clero en Madrid y los ataques a los bienes de la Iglesia, José Francisco GuiJARRO, Persecución religiosa y guerra civil. la Iglesia en Madrid 1936-1939, Madrid, La Esfera de los Libros, 2006.

${ }_{95}$ El Gobierno no podía evitarlo, pues carecía de las fuerzas coactivas indispensables. Los verdaderos responsables fueron los sublevados: los que declararon la guerra civil desarticulando totalmente a un pueblo», Francisco LaRgo CABALLERo, Mis recuerdos. Cartas a un amigo, México, Ediciones Unidas $1976,166$.

${ }^{96}$ Sobre la vida de los refugiados, España a través de los informes diplomáticos chilenos: 19291939, selección, introducción y notas de Juan Eduardo Vargas... [et alt.]; Juan Ricardo Couyoumdjian y Carmen Gloria Duhart, Santiago de Chile y Madrid Ministerio de Relaciones Exteriores de Chile y Consejo Superior de Investigaciones Científicas, 1994.

${ }^{97} \mathrm{El}$ informe terminaba contando los detalles de su salida de Madrid. Silvio Sericano-cardenal Pacelli, 10 enero 1937, ASV AES Spagna IV 889/265 63-83.

98 Isidro Gomá-Cardenal Pacelli, 26 junio 1937, Archivo Gomá... tomo 6, 232 y ASV AES Spagna IV 891/271 13-14.

Hispania Sacra, LXII

126, julio-diciembre 2010, 723-756, ISSN: 0018-215-X 
ron otros sacerdotes. Los juicios, condenas y cumplimiento de penas eran conocidas por el Delegado Apostólico y por el obispo, Javier Lauzurica y Torralba, Administrador Apostólico. ${ }^{99}$

Al poco tiempo, dimitió Manuel Irujo como ministro de Justicia. Le sustituyó el 10 de diciembre de 1937 Mariano Fructuoso Ansó Zunzarren, primer alcalde de Pamplona con la República, y diputado electo en las listas de Izquierda Republicana. En su discurso dijo: cuando se trata de defender la República «hay que pasar por encima del derecho». Lo dijo una persona considerada ajena al fanatismo, incluso inmune al «fanatismo de la ley».

José María Torrent, sacerdote del Oratorio, responsable de la iglesia en Barcelona, tras la prisión del obispo Manuel Irurita, estuvo con Irujo, cuando quiso abrir algunos lugares de culto en Barcelona. ${ }^{100}$ Torrent dijo que no era el momento aún. Los vascos tenían en el domicilio social de sus organizaciones culto privado, con numerosa asistencia. Pero esos locales eran pequeños. ${ }^{101}$

Desde unos llamados «Archives Espagnoles, 7 B. Haussmann, París, se envió el folleto À propos de la lettre collective des évêques Espagnols», editado en la Imprimerie Centrale, Rue Erad, París, sin fecha.

Este texto de 134 páginas, se abre con la famosa fotografía de los obispos saludando con el brazo extendido y con otra de un obispo, esta vez ante un grupo de hombres alzando su fusil. Las dos fotografías enmarcan el sentido del texto: la complicidad criminal de la Iglesia, obispos, clero, religiosos y CEDA, propietarios y capitalistas católicos en la rebelión, no en la guerra civil. Arranca desde la represión por la Revolución de Asturias. Destaca el resultado electoral, con una presencia de 200 diputados de la derecha, que aceptó de la legalidad de los comicios de febrero...

Todo es propaganda, legítima, pero burda en la apreciación de los hechos y en la manipulación de los mismos. Todo muy bien para quien desconoce los hechos y es receptivo al mensaje de quien redacta esa propaganda. Sucede siempre.

En respuesta a un despacho suyo, Pacelli contestó a Ildebrando Antoniutti: el Papa lamenta la campaña de algunos sacerdotes vascos contra el cardenal Isidro Gomá y contra la España nacional. Estaba previsto pedir a los obispos, en

\footnotetext{
99 Esta documentación en ASV Archiv.Nunz.Madrid 972 193-407.

100 Vicente CÁRCEL ORTí, Diccionario de sacerdotes diocesanos españoles del siglo XX, Madrid, Biblioteca de Autores Cristianos 2006, 1138-1142. Torrent era vicario general de Barcelona. Sobre su posición ante los intentos de restaurar el culto católico en la zona republicana, Vicente CÁrCEL, Pío XI entre la República... 215-231.

101 Torrent-Cardenal Pacelli, 1 febrero 1938, ASV AES Spagna IV 891/272 23-24.
} 
cuyas diócesis residían, que tomaran medidas para que observaran la disciplina de la Iglesia.

Se envió copia al cardenal Gomá. Este, al agradecer esa información, comenta: el problema de los católicos vascos ha sido uno de los más delicados originados por la guerra.

«El de la intervención de los sacerdotes vascos, primero en la desviación del sentimiento político de los fieles de Vasconia, arrastrándoles a una nefanda colaboración con los comunistas, y luego en la campaña inicua contra España, llevada desde el extranjero, y contubernio con los tradicionales enemigos de la religión y de la patria, utilizando, como ellos, la calumnia y la mentira, ha sido uno de los más graves problemas que se han planteado en el curso de la contienda actual, por cuanto la condición de católicos de que se glorían los vascos ha podido inducir a error, al enjuiciar los asuntos de España, a muchos extranjeros».102

La apertura de la documentación vaticana para el período 1922-1939 permite completar algunos aspectos polémicos de aquellos años y de los posteriores. ${ }^{103}$ Cuando se planteó la cuestión del apoyo de la Santa Sede a las demandas de los jelkides en 1911, el cardenal Vives i Tutó pronosticó que, en la hora decisiva, estos usarían la religión como un medio para sus fines políticos. ${ }^{104}$ Es verdad que esa sospecha se produce en el contexto de la crisis modernista y de la resistencia de quienes no aceptaron en Italia el pacto entre conservadores y católicos, propiciado por Pío X, porque juzgaban que esa decisión era un abuso de autoridad y un error político.

El nacionalismo era ya en los años treinta una amenaza para la paz y la supervivencia de las sociedades liberales. ${ }^{105}$ Lo mismo pensaba en 1936, desde una perspectiva antiliberal y conservadora, el cardenal Segura. ${ }^{106}$

102 Isidro Gomá-Ildebrando Antoniutti, 23 junio 1938, Archivo Gomá... tomo 10, 302-303 y ASV Arch.Nunz.Madrid 970 102-103.

103 «Una visita interesante», La Gaceta del Norte 19 de enero, 1. La fuente, El Noticiero Bilbaíno. Deterioradas las relaciones con los nacionalistas, La Gaceta del Norte subrayó y recuadró la noticia. El contexto, José Luis de la GRANJA SaINZ, Nacionalismo y II República... 536, 543-544 y 560-565. Sobre sus conversaciones con Giuseppe Pizzardo, sustituto de la Secretaría de Estado, ibidem 544-545. El relato más completo, I. MoRioneS, «Euzkadi y el Vaticano (1935-1936), Roma 1976. Vid. también Juan de ItURRAlde, La guerra de Franco, los vascos y la Iglesia, tomo I, San Sebastián 1978, 305-312.

104 «El Vaticano y los nacionalistas vascos (1910-1911)», Scriptorium Victoriense 35 (1988) 163205. En este conflicto de los bizkaitarras con el obispo de Vitoria sobre el bautismo usando nombre vascos, José María de Urquijo les dio su apoyo. Lo sabía el obispo Ramón Fernández de Piérola.

${ }^{105}$ En 1939 apareció un estudio sobre nacionalismo, encargado por el Royal Institute of International Affairs, de Londres. Se consideraba el nacionalismo un peligro para el futuro de la civilización. Juan Pablo Fusi, La patria lejana. El nacionalismo en el siglo XX, Madrid, Taurus 2003, 83 y 98.

${ }^{106}$ Cardenal Segura-Fal Conde, 9 octubre 1936, en Santiago MARTínEZ SÁnCHEZ, Lo papeles perdidos del cardenal Segura. 1880-1957, Pamplona, Eunsa 2004, 381.

Hispania Sacra, LXII

126, julio-diciembre 2010, 723-756, ISSN: 0018-215-X 
La pastoral de Mateo Múgica, obispo de Vitoria, y de Marcelino Olaechea, ${ }^{107}$ obispo de Pamplona ${ }^{108}$ levantó acta del conflicto provocado por los nacionalistas poniéndose al lado de quienes destruían iglesias y asesinaban a católicos. ${ }^{109}$

No puede decirse que su redactor, el cardenal Gomá, por esas fechas, desconociera la realidad. En el bando alzado había gentes que veían «profundamente herida su conciencia católica por las leyes sectarias y laicizantes y por las desenfrenadas persecuciones». Otros, por considerar «amenazados sus intereses materiales» ante la previsible implantación de un régimen comunista. Algunos estaban en favor de una sociedad con paz y con orden. Otros se movían por la defensa de la nación frente al separatismo, siendo este aspecto una tragedia que enfrentaba a católicos, ${ }^{110}$ ya que los nacionalistas vascos estaban con el Frente Popular. ${ }^{111}$

107 Este último, obispo de Pamplona, conocía los cambios entre sus fieles. Hablaba de un «estado de indisciplina social antirreligiosa» y de una nueva «generación nueva, casi de hecho laica». Javier DRONDA, «La influencia de la Iglesia en Navarra al llegar la República», Cuestión religiosa y democracia republicana en España (1931-1939), Javier Dronda y Emilio Majuelo (coord) Universidad Pública de Navarra 2007 110-112.

108 Un status quaestionis, en Francisco RodRíGUEZ DEL CORO, «El obispo Olaechea y su pastoral conjunta sobre el nacionalismo vasco (1936)», http://www.euskomedia.org/PDFAnlt/vasconia/ vas04/04237267.pdf. Problemas para difundir el documento, Mateo Múgica-Isidro Gomá, 6 agosto 1936, Archivo Goma... tomo 1 69-70. La respuesta del cardenal Isidro Gomá,11 agosto. Instó el 21 de agosto al obispo de Vitoria para que el escrito tuviera mayor difusión en la parte Guipúzcoa y Vizcaya. Mateo Múgica dijo que hacía todo lo posible «para apoyar el esfuerzo redentor del ejército español». Mateo Múgica-Isidro Gomá, 23 agosto, ibidem 78-79, 92-93 y 97-99. El día 20 envió una circular a los párrocos con el documento del 6 de agosto «a fin de que usted transmita su contenido a los demás sacerdotes y feligreses de su parroquia», ibidem 100 .

109 Sobre la conducta de la Santa Sede estos primeros meses, Vicente CárCEL ORTí, Pío XI entre la República... 159-229, y sobre la actitud del Papa ante los nacionalistas vascos católicos, ibidem 275-281.

110 Aclarar ante la opinión pública internacional el equívoco de que hubiera católicos en el bando republicano fue el primer objetivo de la Carta Pastoral Colectiva, 1 julio 1937. Documentos Colectivos del Episcopado Español. 1870-1974, edición completa preparada por Jesús Iribarren, Madrid, Biblioteca de Autores Cristianos 1984, 219-249. La posición de Isidro Gomá, Rodríguez Aisa, El cardenal Gomá y la Guerra de España... 415-418, 461-463 y 479-480. Los documentos relacionados con este documento, Archivo Gomá... 6: junio-julio1937... 213, 514-515, ibidem 7: agosto-septiembre 1937, 339-340 y 497-498, tomo 9: enero-marzo 1938, 570-571.

111 Informe sobre el levantamiento cívico militar en España en julio de 1936, de Gomá-Pacelli, 13 agosto 1936, anexo 2 en M Maisa RodRíGuEz AISA, El cardenal Gomá y la Guerra de España. Aspectos de la gestión pública del Primado 1936-1939, Madrid, Consejo Superior de Investigaciones Científicas 1981, 371-378, Editado también en Archivo Gomá... tomo 1, 80-89. Temía el cardenal que los motivos de quienes «ofrendaban su vida» para defender la religión, quedaran defraudados «al liquidar la victoria». Este aspecto lo subrayó Gonzalo REDONDO, Historia de la Iglesia en España. 1931-1939. I: La Segunda República, Madrid, Rialp, 1993, 67.

Sobre la intervención de Gomá y de la Santa Sede en el problema de los nacionalistas vascos, María Teresa RodRíGuez AISA, El cardenal Gomá y la Guerra de España... 61-65, 83, 181, 186, 202, 234 235 y 380. La oferta de Gomá a Franco para mediar ante ellos, por sí mismo o por el obispo de Vitoria cuando se le pidió que la Iglesia los desautorizara, Gomá-Pacelli, 1 enero 1937, anexo 15, ibidem 404. 
Desde que se instauró la República, muchos católicos, incluidos los obispos, tuvieron que aceptar esa quiebra entre su deber y las posibilidades de cumplirlo, por falta de reciprocidad. No la hubo en el estatuto constitucional dado a la Iglesia. Se agravó con la Ley de Confesiones y Congregaciones Religiosas, un abuso jurídico, una ley poco equitativa. Se convirtió en agresión en octubre de 1934. A partir de febrero de 1936, el nuncio Tedeschini y el encargado de negocios, Silvio Sericano, dirigieron notas de protesta por los ataques a las personas y a los bienes de la Iglesia. Todas quedaron sin respuesta.

Hay una doble vara de medir: pedir a los católicos fidelidad a la República, que los ha excluido, y asistir impasibles a la muerte de los inocentes. ${ }^{12}$ Los crímenes se ignoraron o disculparon, reduciendo a la víctima a un símbolo. ${ }^{113} \mathrm{~A}$ quien se asocia con él, se le puede, se le debe eliminar. ${ }^{114}$

Al poco tiempo de la publicación de la Carta Colectiva del Episcopado, firmada el 1 julio 1937,115 Azaña comentó que la Iglesia había participado en esta guerra como «en una cruzada contra infieles». Cree que se ha equivocado... Incluso si hubiera sido injustamente perseguida, su papel no era ese. «La religión

Más datos sobre la conversación Gomá-Franco, en su informe del 17 de febrero de 1937, anexo 21, ibidem 413-415. La carta de Gomá a Aguirre, 13-1-37, anexo 17, ibidem 407.

112 Aguirre en su carta al cardenal Gomá recordó que no calló ante esos crímenes. Lo hizo el 1 de octubre de 1936, en las Cortes. Ese día se aprobó el Estatuto Vasco.

113 «La misión de la guerra del 36 consiste en destruir al enemigo -el supuesto hermano- totalmente, sin intentar anexionárselo, a fin de vivir con él en hermandad, esto es en rivalidad fraternal». Para Unamuno fue desolador comprobar «la destrucción práctica de toda fraternidad y toda cultura». Estudio de Carlos Feal en Miguel de Unamuno, El resentimiento trágico de la vida. Notas sobre la revolución y guerra civil españolas, Madrid, Alianza Tres 1991, 113 y 123-125. La decisión sobre la memoria histórica, ha hecho que se reediten textos publicados aquellos años. Vid. Paul Claudel, A los mártires españoles, edición bilingüe a cargo de Tomás Salas, Madrid, Ediciones Encuentro 2009.

Georges BeRnanos, Los grandes cementerios bajo la luna, traducción de Juan Vivanco, Barcelona, Lumen 2009.

${ }^{114}$ Como ejemplo de esa posición, José Luis GonZÁLez GulLón, «Leocadio Lobo, un sacerdote republicano (1887-1959«Hispania Sacra 125 (enero-junio 2010) 267-309. El riesgo de confundir intelectual con ideócrata, según la denominación unamuniana, Ralf DAHRENDORF, La libertad a prueba: Los intelectuales frente a la tentación totalitaria, Madrid, Trotta, 2009. Victor OuIMETTE, Los intelectuales españoles y el naufragio del liberalismo (1923-1936) introducción de José Luis ABELLÁN, Valencia, Pre-Textos, D.L.1998. Octavio Ruiz Manjón, «La crisis del sistema demoliberal español y la crítica de los intelectuales», Estudios históricos: Homenaje a los Profesores José María Jover Zamora y Vicente Palacio Atard, v. 1 Departamento de Historia Contemporánea de la Facultad de Geografía e Historia de la Universidad Complutense; presentación de Antonio FERnÁNDEZ GARCíA, Universidad Complutense de Madrid, 1990, 199-220.

115 Sabemos que Franco pidió a Isidro Gomá una carta colectiva para contra-informar respecto a las noticias que circulaban sobre la situación de la Iglesia en España en la zona republicana. Isidro GomáCardenal Pacelli, 8 junio 1937. El 1 de julio informa al cardenal Pacelli sobre los criterios tenidos en cuenta. Esta documentación en Archivo Gomá... tomo 6 81, 321-350. El envío de la carta a los obispos extranjeros, 20 julio, ibidem 514-515.

Hispania Sacra, LXII

126, julio-diciembre 2010, 723-756, ISSN: 0018-215-X 
no se defiende tomando las armas e incitando a los demás a que las empuñen». Echaba en falta, catorce meses después de iniciarse la guerra, el que, al menos, un obispo hubiese pronunciado «las palabras de paz, de caridad, de perdón que les corresponde decir, si de verdad su reino no es de este mundo».

Años más tarde, en el verano de 1940, antes de salir de Arcachon hacia Montauban, mantenía aún esa dura opinión «Lo que ha hecho en España la Iglesia católica no tiene perdón de Dios». Quedaba la amenaza de «un estrago mucho mayor». Si eso volviera a producirse, esta vez sí que la gente «tendrá lo que no ha tenido ahora: razón».116

\section{Posición ReSERVAdA y EXPECTANTE DE LA SANTA Sede}

El nacionalismo vasco fue un problema antes de 1937 y después. Muchos nacionalistas en la zona controlada por los sublevados y en Guipúzcoa y Vizcaya, leales a la República, tuvieron miedo. Fue este uno de los motivos de Mateo Múgica para negarse a firmar la carta colectiva. Política y sentimiento religioso entraron en contradicción en esa «cosa bastante compleja y trágica» que era el problema vasco. ${ }^{117}$

Fuera, el cardenal Vidal i Barraquer tuvo que ocultar que estaba residiendo en Italia, cerca de Lucca, para «no correr el riesgo de probables represalias contra cosas y personas... por parte de los rojos, hasta ahora escapadas de su furor». El cardenal sufría por no estar con los suyos, por no poder «encontrar y congregar el pusillus grex», disperso y desorientado. ${ }^{118}$

El recelo con que el mundo católico, salvo algunos miembros de la CEDA y los que militaban en el nacionalismo vasco y catalán, miraban el porvenir de la Iglesia bajo la República, explican su abstención. Consideraban la guerra una tragedia inevitable. ${ }^{119}$

116 Cipriano de Rivas CHeRIF, Retrato de un desconocido... 483.

117 «Ya supongo que desde el primer momento, pública y sotto voce, nada habrá quedado por intentar para hallarle un arreglo, que nunca será tardío. me hago cargo del enorme distanciamiento que en el orden político existe entre los dos cabos a atar, de ser, por parte de uno y otro sincerísimo el sentimiento de fraternidad religiosa, ¿no podrá pesar este más que aquel y desembocar en un punto de convergencia? ¡Dios mío, qué terriblemente ofusca a los hombres la política».

${ }^{118} \mathrm{La}$ ausencia de pasión política y la preocupación pastoral del Cardenal Vidal i Barraquer le movieron a pedir al cardenal Gomá que expresara «verbal y reservadamente, solo a la persona cerca de la cual ejerce su misión altisima [Franco], mis salutaciones y homenajes de simpatía y afecto y mis sinceros votos de que se logre cuanto antes alcanzar y establecer en nuestra España una paz sincera y perdurable, cimentada en el amor cristiano y en la armónica convivencia de todos los hombres de buena voluntad». Vidal i Barraquer-Isidro Gomá, 9 febrero 1937, Archivo Gomá... 3. Febrero 1937 158-160.

119 Meer cuenta el testimonio de José Luis Gaytán de Ayala. En junio de 1936, en una comida que tuvo lugar en casa de Francisco Horn, Alberto de Onaindía admitió que un golpe militar, en las circuns- 
En una entrevista, al encargado de negocios de la Santa Sede ante el Gobierno de Burgos, planteó el 3 de febrero de 1938 el cardenal Isidro Gomá la conveniencia de que el Papa, en la forma que creyera mejor, aprobara la Pastoral Colectiva. No creía que la iniciativa debiera ser suya. ${ }^{120}$ La tomó Antoniutti escribiendo al cardenal Pacelli el 9 de febrero. ${ }^{121}$

El 8 de marzo, el cardenal Pacelli envió a Pamplona, donde se hallaba el cardenal Isidro Gomá, la noticia de que la Santa Sede se hacia eco de la favorable acogida y de la gran «resonancia» de la Carta Colectiva. La carta condenaba el mal hecho y ofrecía generoso perdón por todos los daños sufridos por la Iglesia en la persona de sus obispos, de su clero y de sus fieles, así como en sus bienes. ${ }^{122}$

El texto de cardenal Pacelli era un gesto de apoyo, hasta en lo personal, pues le decía que el Papa se alegraba de que hubiera recuperado Isidro Gomá la salud. Importa que nada se decía abiertamente sobre el documento, limitándose a darse por enterado de su repercusión entre los otros episcopados del mundo. ${ }^{123}$ Era suficiente.

Hubo una labor humanitaria del delegado de la Santa Sede en San Sebastián y Bilbao en 1937. La oposición de los nacionalistas a la repatriación fue un obs-

tancias en que se hallaba España era lícito desde el punto de vista de la moral católica, El Partido Nacionalista Vasco 43-46 y 78. Sobre la versión religiosa del conflicto aquellos años, Juan de la CRUZ MARTíneZ, ¿Cruzada o rebelión?, Zaragoza 1938. Ignacio MENÉNDEZ ReIGADA, La guerra española ante a moral y ante el derecho y Acerca de la guerra santa, Salamanca 1937. Constantino BAYLE, Sin Dios y contra Dios, Burgos 1938. Aniceto CASTRo AlbarRán, Guerra Santa. El sentido católico de la guerra española, Burgos 1938. Alfonso Álvarez BolADO, «Guerra civil y universo religioso. Fenomenología de una implicación» Miscelánea Comillas 44 (1986) 233-300; 45 (1987) 417-505; 47 (1989) 3-86; 48 (1990) 35-97 y 49 (1991) 23-98. Antonio FERNÁNDEZ GARCíA, «La Iglesia española y la guerra civil», Studia Historica III/4 (1985) 37-74. La influencia de la religión en la primera fase del régimen, Josep María Margenat Peralta, El factor religioso en la construcción del consenso del Nuevo Estado franquista (1936-1937), Tesis doctoral, Ediciones de la Universidad Complutense 1991.

120 «Nota conversación Delegado Pontificio» 3 febrero 1938, ASV Arch.Nunz.Madrid 970 66. El documento está editado como «Nota elaborada pior lel card. Gomá de los asuntos a tratar Por D. Luis de Despujols con mons. Antoniutti sobre diversas cuestiones políticas y eclesiásticas», Archivo Gomá... tomo 9 238-240. En esos momentos el cardenal Gomá juzgaba conveniente que, aprovechando el nuevo rumbo de la situación política, en la que destacaban los avances militares y la reforma de la legislación republicana, la Santa Sede adoptara una posición nueva.

${ }^{121}$ Minuta del despacho, copia enviada a Isidoro Gomá, 9 febrero 1938, ibidem 143-144.

122 Conforme se fueron publicando estas respuestas, la posición de la Santa Sede pareció más clara. El conde Dalla Torre, director del L'Osservatore Romano, publicó un editorial. La Iglesia, primera víctima de la guerra civil, ella no era combatiente. Ha sido mártir. La causa de Dios no puede ser arrastrada hasta confundirse con una causa de los hombres.

123 «La Santa Sede y España. Testimonio a favor de la Carta Colectiva del Episcopado», Vaticano 5 de marzo 1938, Diario Vasco 23 abril 1.

Hispania Sacra, LXII

126, julio-diciembre 2010, 723-756, ISSN: 0018-215-X 
táculo. Ese problema fue, a la vez, una denuncia de la conducta del Gobierno vasco durante el sitio de Bilbao. ${ }^{124}$

¿Quién fue responsable del resultado electoral en 1936? La derecha, que condenó a los nacionalistas. ${ }^{125}$ Esa fue la tesis del PNV, compartida por el obispo Mateo Múgica. Su gestión de última hora, a petición de las derechas y a través de Antonio Pildain, salió mal. José María de Urquijo se negó a recibir al canónigo y ex diputado en la candidatura unitaria, que venció en las elecciones de 1931.126

Diametralmente opuesta era conclusión de los adversarios del PNV. En la encrucijada de febrero de 1936, sus dirigentes «prefirieron la política a la religión, y su órgano principal, Euzkadi, se preocupó más de medrar políticamente que de defender la religión en toda su integridad. Esta subversión de principios selló «con caracteres de catástrofe gran parte de la región vasca». Con esa conducta habían dividido a las fuerzas católicas, incurriendo así en la condena de la Iglesia. ${ }^{127}$ Sólo la obcecación pudo mantenerlos al lado del Frente Popular. ${ }^{128}$

124 «En favor de los víctimas de la guerra», Hispania Sacra 124 (julio-diciembre 2009) 691-753.

${ }^{125}$ La decepción de los nacionalistas vascos ante la política de la derecha la recogió José Antonio de Aguirre en su escrito, Entre la libertad y la revolución, 1930-1935; La verdad de un lustro en el País Vasco. Bilbao, 1935. Lo recordará en su carta dirigida al cardenal Gomá el 9 de marzo de1937: allí anunció la tragedia de la guerra civil y la posición del PNV.

126 «Los periódicos de derechas, señaladamente La Constancia, de San Sebastián para las elecciones de 1934, y ésta y La Gaceta del Norte para las del 36, hicieron campaña en favor de la derecha sosteniendo que era ilícito y pecado votar a los nacionalistas. Estos acudieron a mi autoridad para defenderse de semejante campaña que tocaba a su honra de católicos y suscitaba una cuestión moral y de conciencia y tuve que intervenir en 1934, por medio de mi vicario (...) luego obispo de Oviedo, y en 1936 por mí mismo, ordenando que ningún político puede esgrimir el argumento de la licitud o pecado, que sólo toca definir a la autoridad eclesiástica y que esta declaraba que esos partidos eran igualmente católicos y que, por tanto, los católicos podían votar a unos o a otros, según sus preferencias políticas, en las que no tenía que meterme... la declaración fue oportuna, pues fue hecha poco antes de las elecciones para tranquilizar las conciencias y a tiempo para impedir el chantage que, con el supuesto pecado, querían hacer las derechas para dejar en mal lugar a la religión ante la masa nacionalista». Mateo Múgica-Pacelli, Gooveind, 22 de febrero de 1939, en respuesta al informe que el cardenal Gomá presentó en abril de 1936. Para Gorka Aulestia esta carta está escrita «con la libertad de quien no tiene nada que perder», Estigmatizado por la guerra, Bilbao, Euskaltzaindia, Real Academia de la Lengua Vasca, Académie de la Langue Basque 2008, 135-140. Juan de ITURRALDE, La guerra de Franco, los vascos y la Iglesia, tomo I, San Sebastián, Gráficas Izarra 1978, pp. 325, 330 y 195-196.

127 Prólogo del Administrador Apostólico de Vitoria, Javier Lauzurica, a P. Pedro AltABELla GRACIA, El catolicismo de los nacionalistas vascos, Madrid, Editora Nacional 1939, 10 y 12 . Altabella niega que el clero vasco hubiera podido pronunciarse libremente durante el tiempo en que gobernó José Antonio de Aguirre en Vizcaya, ibidem 15-47

${ }^{128}$ Los asesinatos de sacerdotes en Larrínaga, El Carmelo y Los Ángeles Custodios y en el buque prisión «Cabo Quilates», probaban complicidad de Aguirre y su gobierno. «Il finale dell'equivoco basco» y «Le tragiche conseguenze dell'equivoco basco», L'Avvenire d'Italia, 2 e 6 luglio 1937. El primero de estos dos artículos lo comentó con el cardenal Pacelli el encargado de negocios de España. 94 Pablo de Churruca-Secretario de Relaciones Exteriores, 2 julio 1937, Archivo Ministerio Asuntos 
¿Qué sucedió? ${ }^{129}$ Ninguna respuesta puede ignorar que la victoria electoral en la izquierda en febrero de 1936 derivó hacia una revolución. Fracasó el pronunciamiento militar que quiso evitarla. La revolución y la guerra civil fueron de la mano en los dos bandos. El derecho y la ley cedieron ante la violencia. Aquella tragedia fue una guerra «incivil» de toda España contra sí misma. Venía preparada por esa negación de tolerancia y diálogo con el otro, que marcó las dos legislaturas anteriores a la de 1936.

Unamuno escribió el sábado 8 de agosto de 1936: «La experiencia de esta guerra me pone ante dos problemas, el de comprender, repensar, mi propia obra... y luego, comprender, repensar España». Reflexión frente al rencor. Frente a la espada, la cruz, no la cruz invertida, en este caso convertida en cruzada. ${ }^{130}$ En ella derramó su sangre el Cristo. El mismo que sudó gotas de sangre en su agonía. Sangre sobre la tierra y como luz, frente a la tentación de usar esa «espada envenenada. ${ }^{131}$ La paz es obra de quienes creen en la ley y en el derecho, en la justicia y en la libertad. Ni la conservan ni la restauran quienes, traicionando su misión, alientan la violencia. En aquel año de gracia de 1937, según Aguirre, atentaban contra la paz, los que animaban la rebelión contra la República.

Ser individuo es ser solitario. Caminar a pie y sin seguir caminos. Es suficiente la palabra como viático. Por ella y gracias a ella, dar vida y no quitarla, dejarse matar y no matar. ${ }^{132}$ En la tumba de una de las personas citadas en estas páginas, José María de Urquijo, hay esta conciso epitafio: «testis Christi occisus». Cuando pereció el hombre, cuando se aletargó en la noche su condición de próximo, se pudo matar sin causa, sin nombre...

Exteriores R 602. Los artículos del diario católico italiano reproducían un comentario aparecido el 25 de junio de 1937 en La Gaceta Regional, de Salamanca.

${ }^{129}$ La pregunto por lo que no sucedió, por lo que Unamuno llama «ex-futuro, lo que habría sido si no hubiera sido lo que fue, es pertinente. Ni hecho desnudos ni fatum ni providencia o sucedáneos, que creen que la historia está determinada. Imaginar esa posibilidad vacuna contra «leyendas contradictorias» y alienta una ética de perdón. «La Historia en plano», Ahora 2 mayo 1936, Ensueño de una patria... 278-281.

130 Marcos Aguinis, La cruz invertida, Barcelona, Planeta 1970. Esta denuncia profética del autor argentino, premio Plantea de aquel año, fue una denuncia de la injusticia y del recurso a la violencia apelando a la religión.

131 «Han hecho del Evangelio, texto de abominación, de tu ley, una cruzada, ;sangre, robo y destrucción» (Romance VII, Romancero del destierro, 1927).

132 «Hay que hacerse mártires, esto es, testigos de la cultura». Palabras de Miguel de Unamuno, en septiembre de 1934, en su última lección universitaria, citado por Carlos FEAL en El resentimiento... 133 Vid. la alusión a la pena de muerte, con la que Unamuno cierra La agonía del Cristianismo, en París, diciembre de 1924, edición de Víctor Ouimette, $8^{a}$ edición, Madrid, Espasa Calpe 1996, Introducción, 188.

Hispania Sacra, LXII

126, julio-diciembre 2010, 723-756, ISSN: 0018-215-X 
¿Quién podrá justificar siquiera el riesgo de que eso pudiera suceder de nuevo? Hay que salir de esa religión «de este mundo», que agrupa para distanciar y enfrentar. Hay que ponerse en guardia ante quienes creen que «pertenecer» es estar en la verdad.

Muchos fueron asesinados, sin preguntar si quiera su nombre. Eran el enemigo. Eliminarlo era una necesidad. Quienes creen que «algo habrían hecho» las víctimas, se encanallan. Esto ha sido una señal de lo de lo que sigue siendo «el problema vasco».

Quienes pervierten las palabras para eludir esta tragedia, no son seguros. Quizás la justifican de ese modo. Quienes todo lo mezclan, para, en la confusión, decir: todos inocentes, todos culpables, envilecen la justicia. Conocer es un deber ético.

En realidad, aquellas vísperas electorales de 1936 el dilema no era «Lenin o Cristo». Ni lo era: «Euzkadi o España». Ni siquiera el futuro de la religión o los intereses de la Iglesia. Nadie es inocente, si, en nombre de algo, desprotege al indefenso. Lo que estaba en juego era el modo de asegurar el respeto al derecho y a la ley. Hemos visto que así lo entendió en las semanas siguiente a las elecciones Manuel Azaña. Por esa vía, ni siquiera La Gaceta del Norte, le rehusó su apoyo. Fueron otros quienes sí se lo negaron. De ello venía hablando Miguel Maura desde noviembre de 1934. Lo reiteró en el verano de 1936, como hemos visto. La derecha se equivocó no rectificando el sectarismo de la mayoría parlamentaria de las Cortes Constituyentes.

Provocó a las organizaciones obreras, a los republicanos burgueses, resucitando prácticas caciquiles. Se retaba a aquellas a que llevasen adelante sus amenazas de revolución. Y esto se hacía en las Cortes. El Parlamento se consagró a derribar la obra de las Cortes Constituyentes. Se jactaron de haber provocado la revuelta contera la República para aplastarla. No fue así, porque «ni la vencieron en su espíritu ni en su raíz, ni siquiera supieron sancionarla con justicia y castigar a los culpables con equidad».133

La noche del 18 de julio, cuando acababa de iniciar su veraneo en La Granja (Segovia), Azaña llamó a Miguel Maura. Estaban reunidos todos los notables de la República y le invitaba a acudir al Palacio Nacional. Puso Miguel Maura como condición que se aceptase la solución que había explicado en los artículos publicado en El Sol entre el 16 y el 27 de junio. La mayoría de los reunidos, según Azaña, estaban de acuerdo, pero Largo Caballero puso su veto: se desencadenaría una revolución dirigida «por las masas obreras».

133 Miguel MaURA, «Una política suicida» y «Suversión y definitivo desprestigio del sistema parlamentario», El Sol, 18 y 20 junio 1936, en Así cayó Alfonso XIII. De una dictadura a otra. Edición de Joaquín Romero Maura, Madrid, Marcial Pons Historia 2007, 510-520. 
En el lado menos visible, esa misma noche, un «correligionario» de Segovia le avisó que los falangistas estaban haciendo una purga entre los republicanos. Irían a La Granja para hacerse cargo del Palacio y del pueblo. En dos coches, salieron hacia Madrid. Aquí, Felipe Sánchez Román le dio más detalles: Largo Caballero dijo que convocaría una huelga general en toda España a favor de la revolución social. Pese a su ascendiente sobre Largo Caballero, Sánchez Román no logró convencerle de que esa salida era un grave error. ${ }^{134}$

Luego vinieron la violencia, la mentira, la guerra, el resentimiento pero también hubo llamadas a que el futuro de la paz se cumpla. Se ha cumplido, salvo para algunos.

134 Miguel Maura, «Recuerdos del 18 de julio», nota manuscrita, Así cayó Alfonso XIII. De una dictadura a otra. Edición de Joaquín Romero Maura, Madrid, Marcial Pons Historia 2007, y 551-552. 